\title{
The real effects of regulatory enforcement actions: Evidence from U.S. counties
}

\author{
Piotr Danisewicz \\ Bangor Business School, Bangor University \\ Danny McGowan \\ Bangor Business School, Bangor University \\ Enrico Onali \\ Bangor Business School, Bangor University \\ Klaus Schaeck* \\ Bangor Business School, Bangor University
}

\begin{abstract}
We highlight an important macro-financial linkage: Regulatory enforcement actions on banks significantly reduce local economic growth. Exploiting the fact that regulatory enforcement actions impose shocks on bank business activities beyond the control of bank executives, and controlling for loan demand conditions, we use difference-in-difference estimations to demonstrate that severe actions such as Formal agreements and Cease and desist orders imposed on single-market banks reduce personal income growth in rural U.S. counties by 0.7 and 0.4 percentage points, respectively. These effects are causally related to contractions in bank lending and liquidity creation. Our identification is sharpened by a series of tests based on placebo enforcement actions that have no ramifications for local economic growth, and propensity score matching and instrumental variable techniques that account for the non-random assignment of regulatory actions.
\end{abstract}

Keywords: $\quad$ bank distress, enforcement actions, local economic growth, macro-financial linkages JEL codes: $\quad$ G21; G28; 043

\footnotetext{
* Correspondence to: Klaus Schaeck, Bangor Business School, Bangor University, Hen Goleg, College Road, Bangor LL57 2DG, United Kingdom. E-mail: klaus.schaeck@bangor.ac.uk. We are grateful to Martin Brown, Steven Ongena, and Qingwei Wang for stimulating discussions, and we thank seminar and conference participants at Bangor Business School, and at the Multinational Finance Meeting, Krakow, for helpful comments. Financial support from the British Academy (Grant No. SG120397) is gratefully acknowledged.
} 


\title{
The real effects of regulatory enforcement actions: Evidence from U.S. counties
}

\begin{abstract}
We highlight an important macro-financial linkage: Regulatory enforcement actions on banks significantly reduce local economic growth. Exploiting the fact that regulatory enforcement actions impose shocks on bank business activities beyond the control of bank executives, and controlling for loan demand conditions, we use difference-in-difference estimations to demonstrate that severe actions such as Formal agreements and Cease and desist orders imposed on single-market banks reduce personal income growth in rural U.S. counties by 0.7 and 0.4 percentage points, respectively. These effects are causally related to contractions in bank lending and liquidity creation. Our identification is sharpened by a series of tests based on placebo enforcement actions that have no ramifications for local economic growth, and propensity score matching and instrumental variable techniques that account for the non-random assignment of regulatory actions.
\end{abstract}

Keywords: bank distress, enforcement actions, local economic growth, macro-financial linkages

JEL codes: $\quad$ G21; G28; 043 
Does local economic growth respond to shocks in bank business activities? And if so, how large is the effect? Answering these questions is key to understanding macro-financial linkages. Moreover, it is also central to understanding how banks react to the regulatory environment, a timely question of relevance for academics, policymakers, and the public alike against the background of far-reaching changes in banking regulation following the signing into law of the Dodd-Frank Wall Street Reform and Consumer Protection Act.

Empirically, establishing these effects is challenging because of well-known identification problems. Local economic growth, bank lending, and bank health are endogenously determined. It is easy to observe that bank lending responds to economic conditions, and that bank health depends on the economic environment. Reverse causality issues are omnipresent.

In this paper, we use exogenous shocks imposed on bank business activities by the Federal Deposit Insurance Corporation (FDIC), the Federal Reserve System (Fed), and the Office of the Comptroller of the Currency (OCC) to identify their effect on economic growth in U.S. counties through lending and liquidity creation, and establish the magnitude of the effects. Our identification strategy exploits enforcement actions for banks that operate in geographically delimited markets, defined by county borders. Focusing on regulatory enforcement actions is important to overcome the main identification challenge because regulatory actions are independent of strategic decisions of bank managers which may be conditional on the local economic environment. Moreover, endogeneity concerns are further mitigated because enforcement actions are observed at the bank level, whereas our key dependent variable, personal income growth, is measured at the county level. Thus, the treatment effect from enforcement actions is exogenous with respect to economic growth.

To the extent that bank credit has no close substitutes as argued by Diamond (1984) and James (1987), we hypothesise that enforcement actions which affect the scope and scale of bank activities trigger reductions in economic growth. ${ }^{1}$ This hypothesis reflects that enforcement actions typically reduce banks' ability to intermediate loans and deposits. Since banking markets are local in nature (Adams, Breevort, and Kiser, 2007), we focus on enforcement actions in single market banks that operate within clearly defined geographical boundaries because we expect this effect to be more pronounced there.

A few studies examine direct effects of enforcement actions which can range from civil money penalties to restrictions on services such as deposit taking or provision of credit. Peek and Rosengren $(1995,1996)$ demonstrate that loan portfolios shrink, especially real estate loans, following enforcement actions in the U.S., and Berger, Bouwman, Kick, and Schaeck (2012) highlight that regulatory interventions disrupt liquidity creation in Germany. However, this literature has so far not yet examined the real effects of enforcement actions beyond the micro level.

Our work is also related to the literature on the real effects of bank distress, and studies that analyse how credit and liquidity supply shocks to banks impact the real sector. Bernanke (1983) and Calomiris and Mason (2003) show loan supply shocks reduce local economic output, and Ashcraft (2005) suggests bank failures reduce county income. A growing literature focuses on how corporate investment and access to credit deteriorate when banks' liquidity supply contracts

1 Event studies suggest bank credit lacks substitutability. Slovin, Sushka, and Polonchek (1993) and Ongena, Smith, and Michalsen (2003) report adverse valuation effects for corporate borrowers when their banks experience distress. Their results indicate a reduction in bank durability affects borrower welfare. 
(Gibson, 1995; Peek and Rosengren, 1997, 2000; Kang and Stulz, 2005; Gan, 2007; Khwaja and Mian, 2008; Lemmon and Roberts, 2010; Chava and Purnanandam, 2011; Schnabl, 2012).

While the studies that home in on the effects of enforcement actions suggest immediate effects on bank behaviour, the question whether these enforcement actions affect the real economy remains an empirical issue. To the extent they do, they have potential to give rise to unintended and possibly undesirable consequences for economic growth, suggesting a transmission mechanism by which regulatory behaviour has real economic impact. This is the subject of our research. We are not aware of any other study that identifies such effects.

To address this phenomenon, we combine data for 9,204 banks operating in 2,023 U.S. counties (15,329 county-year observations), with 828 regulatory enforcement actions, and macroeconomic variables for the period 2001 to 2009. In separate tests that explore the transmission channel through which enforcement actions affect growth, we additionally examine their effects on different lending categories and liquidity creation. The latter is based on a new measure of bank liquidity creation (Berger and Bouwman, 2009).

Exploiting the variation in the occurrence of enforcement actions within counties across time, we use a difference-in-difference (DD) estimation technique to recover the treatment effects on sharp changes in bank lending, liquidity creation, and ultimately, local economic growth.

Consistent with the assumption of exogeneity of treatment, we show treatment and control groups evolve similarly in the pre-treatment period. However, counties that witnessed enforcement actions display significantly different behaviour in the years following initiation of these actions, suggesting that causal inference is possible.

Our main result suggests that severe enforcement actions which impose restrictions on bank activities such as deposit taking and origination of credit exert significantly negative effects on real per capita personal income growth on the county level. This effect is substantial in terms of its economic magnitude: Formal agreements and Cease and desist orders are associated with 7 and 4 percentage point reductions in personal income growth, respectively. In contrast, less severe actions that typically come in the form of civil money penalties display no effect on growth. These results are robust to the inclusion of control variables, including measures of demand for credit supply using the Senior Loan Officer Survey on Bank Lending from the Federal Reserve System. To sharpen the causal inferences, we also generate placebo enforcement actions which we find to have no effect on growth.

Our exploration of the transmission mechanism suggests that these macro-financial linkages are attributable to contractions in bank lending. In particular, we observe reductions in lending to the commercial and industrial sector, the real estate sector, the construction industry, and the farming sector. We also find that liquidity creation declines following enforcement of severe actions.

The main analyses rely on DD estimations. However, we recognise that enforcement actions may not be assigned at random. We therefore also use propensity score matching techniques, and instrumental variable regressions to confirm the results. While the propensity score matching estimator is not 'bullet' proof due to the selection on observables, the instrumental variable regressions alleviate this problem, lending further credibility to our inferences.

Section 1 discusses the institutional background. Section 2 describes the dataset, and offers a preliminary investigation of basic statistics and our identification strategy. We present results in Section 3, including robustness tests and extensions. Section 4 offers concluding remarks. 


\section{Institutional Background: Enforcement Actions}

In pursuing the aim to maintain a safe and sound banking system, regulatory agencies (FDIC, Fed, and OCC) are charged with the supervision of financial intermediaries.

One of the key tools to achieve this aim are on-site examinations. In instances when these onsite examinations suggest unsafe, unsound, or illegal practices which violate laws, enforcement actions are used to restore safety and soundness by altering bank practices, stabilising the institution, and averting losses to the deposit insurer (Curry, O'Keefe, Coburn, and Montgomery, 1999). Typical reasons for the initiation of enforcement actions are management problems (poor loan administration, insufficient corporate planning, poor internal controls), and financial problems (inadequate capital and inadequate loan loss reserves, poor asset quality, clustering of loan portfolio risks, failure to charge off loan losses, poor liquidity, insider payments, failure to file with regulators). Noncompliance with enforcement actions can result in termination of deposit insurance. Since banks understand their asset choices determine regulatory closure rules, enforcement actions are likely to trigger changes in conduct (Mailath and Mester, 1994).

In our subsequent discussion, we only focus on actions issued against institutions. While enforcement actions can also be issued against individuals, such actions tend to be related to fraud or individuals failing to fulfil fiduciary duties that are not related to the bank itself.

Several different enforcement actions exist. For our main analyses, we group them together into Less severe actions and Severe actions based on their seriousness, disclosure requirements, whether they can be enforced in court, and based on whether they have potential to affect the scope and scale of bank activities (Curry et al., 1999; Ioannidou, 2005). Our grouping reflects both supervisory practice in the U.S., and also considers the Basel Core Principles for Effective Banking Supervision, issued in 2012. We now list the actions in ascending order.

The following types of actions are classified as Less severe actions.

Bank board resolutions are declarations by the bank's board outlining details as to how it will take corrective actions in a given period relating to safety and soundness issues. These resolutions are not disclosed publicly and they are not enforceable. However, failure to honour them results in more serious enforcement actions.

A Memorandum of understanding is a bilateral agreement between the bank's individual board members and the regulator not known to the public. It lays down specific actions and deadlines for the bank as to how to achieve specific objectives. Such bilateral agreements cannot be enforced in court.

Civil money penalties are imposed for violations of laws, regulations, Cease and desist orders, or Formal Agreements. They are publicly known. Typical penalties relate to violations of the Bank Secrecy Act, the Home Mortgage Disclosure Act, and to Call Report infractions. This form of enforcement action carries charges from $\$ 1,000$ to $\$ 1$ million per day, depending on the severity of the penalty.

Suspension, removal, and prohibition orders allow regulators to bar individuals from associating with a bank due to violation of laws, regulations, or other written agreements. ${ }^{2}$ These actions are disclosed.

We consider the following enforcements as Severe actions, all of them are disclosed.

2 Note that when illegal actions of individuals threaten the safety and soundness of the bank itself, a Cease and desist order or a Formal agreement will be issued against the institution as well (Ioannidou, 2005). 
Formal (written) agreements are bilateral agreements between the bank and the regulator which set out details on how to correct conditions which are the basis for the agreement. This type of enforcement action is not followed by a federal court case verdict.

Cease and desist orders are issued following hearings. Unlike Formal agreements, they are imposed on the bank by the regulator. Cease and desist orders, can come in the form of restrictions on bank activities, e.g., on asset growth and the prohibition of asset disposals. Moreover, Cease and desist orders go beyond the restriction of activities and usually require remedial actions to correct violations of laws and improve safety and soundness of the institution. Unlike Formal agreements, they can be enforced in court.

Prompt corrective actions are imposed on undercapitalised banks. This action demands corrective measures to restore adequate levels of capital, and requires submission of a capital restoration plan within a predetermined time period. Depending on the level of undercapitalisation, Prompt corrective actions can trigger dismissals of senior executives, and carry restrictions on executive pay, asset growth, and prohibition of: acquisitions, establishing new branches, issuing new lines of credit, selling company shares, and disposing assets.

Deposit insurance threats are the most severe enforcement action before a bank is placed in receivership, which leads to termination of the banks' charter or sale to other investors.

Table 1 provides an overview about enforcement actions. In total, we observe 361 Less severe actions and 467 Severe actions. We record 209 Formal agreements. Cease and desist orders account for 282 observations, and there are 12 Prompt corrective actions. Regulators have not issued Deposit insurance threats during the sample period for single market banks.

[TABLE 1: Time distribution of enforcement actions]

\section{Data Description and Identification Strategy}

We obtain Call Report data for all commercial banks and savings banks in the U.S. between 2001 and 2009 from SNL Financial. This database also contains information about the timing and type of regulatory actions, branch location information, and deposit market shares from the Summary of Deposits from the FDIC.

We focus on enforcement actions in banks that operate in only one small market, referred to as single-market banks, to allow a better demarcation of the boundaries of the relevant market for which we try to establish the real effects of enforcement actions. Our choice is predicated on the basis that where enforcement actions cause economic disruption, their real effects will be more pronounced within the country where the single-market bank operates, reflecting geographic market segmentation. This segmentation is due to low spatial mobility of bank customers and the information asymmetries inherent in lending relationships (Adams et al., 2007; Felici and Pagnini, 2008). Consequently, the natural unit of analysis is the county. We define a singlemarket county as a county that has at least one single-market bank in each year. Figure 1 illustrates that the majority of counties has at least one single-market bank and the number of counties with single-market banks is increasing over time. Figure 2 shows the counties in which regulatory enforcement actions took place.

[FIGURE 1: Single-market banks]

[FIGURE 2: Enforcement actions in single-market banks]

Our main dependent variable is county-level personal income, obtained from the Bureau of Economic Analysis (deflated using the CPI from the Bureau of Labor Statistics). 


\subsection{Identification Strategy}

The above mentioned endogeneity concerns lead us to adopt DD estimations to establish the effect of enforcement actions. This estimator exploits exogenous cross-county and cross-year variation in different types of enforcement actions. DD estimation compares treatment counties, i.e., counties where single-market banks experienced enforcement actions with counties in a control group where banks did not experience enforcement actions during the sample period. The estimator considers the time difference of the group differences, i.e., it accounts for omitted variables that affect treated and untreated counties equally.

We estimate the following equation

$$
y_{i t}=\alpha+\beta E A_{i t}+\delta X_{i t}+\gamma_{i}+\gamma_{t}+\varepsilon_{i t},
$$

where $y_{i t} i$ s the dependent variable in county $i$ at time $t$; $E A_{i t}$ is a dummy equal to 1 if an enforcement action is issued against a single-market bank in the county at time $t$ ( 0 otherwise); $X_{i t}$ is a vector of control variables, defined in detail below; and $\varepsilon_{i t}$ is the error term. There exist a number of difficult-to-observe variables which may explain growth (e.g., urban counties may have higher growth rates). We capture these time-invariant omitted variables by including county dummies, $\gamma_{i}$, and business cycle fluctuations common to all counties are captured by year dummies $\gamma_{t}$. Inclusion of the year dummies means that the effects of enforcement actions are identified by cross-group variation within the year dimension of the data.

The coefficient of interest, $\beta$, is the slope of the dummy variable for enforcement actions, reported in the regressions below separately for Less severe and Severe actions. A positive slope coefficient suggests that personal income growth increases following enforcement actions whereas a negative coefficient points towards adverse effects for economic growth.

Our vector of control variables $X_{i t}$ contains variables that can affect economic growth.

Most importantly, our focus on credit supply shocks requires isolating demand effects. Note that our regressions already contain county fixed effects which net out differences in taxation across states that affect entrepreneurial activity, and we use year fixed effects that take out the variation in demand conditions across the business cycle (Black and Strahan, 2002). In addition, we use data from the Senior Loan Officer Opinion Survey on Bank Lending Practices from the Federal Reserve System. The survey provides information about credit demand from firms and households. ${ }^{3}$ We use the survey question about whether demand for commercial and industrial loans from small and medium-sized firms has increased over the past three months, and code a variable that captures the percentage of banks that report an increase in demand for loans in this category.

Moreover, we use a Herfindahl-Hirschman Index (HHI) for deposit market shares to control for the structure in local banking markets, and we also account for average firm size, taken from the County Business Patterns database. Both variables are skewed and we therefore take the natural log. We use these two variables to control for the firm structure of the non-financial sector because counties with on average larger firms are likely to grow faster. Cetorelli and Strahan (2006) argue that competition in banking affects access to finance and consequently has

\footnotetext{
The quarterly survey covers loan officers at approximately 60 domestic and 24 U.S. branches and agencies of foreign banks. The surveyed banks are located across all Federal Reserve Districts to ensure broad geographic coverage and between two and ten banks from each district are surveyed. Both large as well as medium-sized regional banks are covered to allow for diversity of responses and offer a broad view of the demand conditions in the banking system. The survey is available from http://www.federalreserve.gov/boarddocs/snloansurvey/.
} 
ramifications on industry structure in the non-financial sector. In addition, we also include population growth (county level) from the U.S. Bureau of Labor Statistics to account for changes in the size of the relevant market. ${ }^{4}$ To reflect on the adverse effects on growth during the recent financial turmoil, we use a crisis dummy that takes on the value one for the years 2007-2009. Table 2 presents descriptive statistics.

[TABLE 2: Summary statistics]

\subsection{Assumptions}

Inferences with DD estimations are only valid when two key assumptions are met. First, assignment of regulatory enforcement actions is exogenous with respect to personal income growth. In other words, (lack of) economic growth in each county is not the not the driving force behind the regulatory enforcement actions. Second, absent enforcement actions, average personal income growth would have been the same for counties in both treatment and control groups. This is the 'parallel trends' assumption.

To what extent are enforcement actions exogenous? As stressed in the introduction, an obvious concern is that bank health, especially in the context of single-market banks, is a product of local economic conditions, and that low growth rates trigger regulatory action such that there exists a simultaneous relationship. Consequently, OLS yields biased and inconsistent estimates of $\beta$.

Visual inspection of Figure 3 suggests that this is not a serious problem: There is no evidence of a systematic relationship between income growth prior to treatment and subsequent regulatory behaviour. In Section 3.1. below, we offer additional econometric tests to support this claim and rule out that that our results are driven by pre-treatment trends within the county using placebo treatment effects.

[FIGURE 3: Timing of enforcement actions]

To check whether the data satisfy the parallel trends assumption, we compare the evolution of personal income growth in the three years prior to the enforcement actions. The parallel trends assumption requires that we can observe similar changes of personal income growth between counties where banks experienced enforcement actions and the counties in the control group. Note that this assumption does not require identical growth levels between treatment and control groups. The key idea of the parallel trends assumption is that personal income growth evolves similarly in treatment and control group counties in the absence of enforcement actions.

Figure 4 shows how annual changes in personal income growth behave across treatment and control group counties. The patterns we observe are very similar and suggest parallel trends. All panels show an increase in personal income growth prior to regulators' actions, and this result holds irrespective of whether we focus on Less severe or Severe actions.

[FIGURE 4: Parallel trends between treatment and control group]

\section{Results}

Table 3 reports our main results using annual data. We cluster heteroskedasticity-adjusted standard errors on the county level to correct for serial correlation within counties (Bertrand, Duflo, and Mullainathan, 2004). We include counties where regulators impose actions on multiple banks across different time periods, although our results are not affected when we

4 Claessens and Laeven (2004) show that concentration within the banking market has important implications on competition between financial institutions which in turn may affect the availability and cost of credit. 
exclude these observations. In Panel A, we present the effect of enforcement actions on personal income growth, and Panel $\mathrm{B}$ and $\mathrm{C}$ explore two key mechanisms that have potential to trigger reductions in personal income growth: Bank lending and liquidity creation. In each panel, we show the effects for both Less severe and Severe actions, and we additionally present specifications where the Severe actions are decomposed into Formal agreements, Cease and desist orders, and Prompt corrective actions.

There is clear evidence that regulatory enforcement actions disrupt the real economy. The coefficients for Less severe and Severe actions in Panel A display negative signs in Column 1, although only Severe actions are statistically significant at the $1 \%$ level. Importantly, the economic magnitude of the effect is substantial against an average income growth rate of $1.1 \%$ : Severe actions cause the rate of personal income growth to decline by 0.5 percentage points.

Column 2 suggests that the magnitude of the contraction in personal income depends on the type of action taken by regulators. Formal agreements have a larger impact on economic growth (0.7 percentage points) relative to Cease and desist orders ( 0.4 percentage points). This is not surprising. First, Formal agreements are issued with the consent of the institution, suggesting a strong commitment of the bank to address the problems and respond quickly. Second, banks have a strong incentive to avoid public attention arising from Cease and desist orders and therefore are keen to portray themselves as adjusting behaviour in line with mutual agreements with the regulator rather than being subject to Cease and desist orders. Third, they also tend to occur prior to the issuance of Cease and desist orders, and many problem banks are examined at a high frequency which results in additional enforcement actions following Formal agreements. Thus, the two coefficients can pick up compounding effects. While Formal agreements are bilaterally agreed and are the first step that triggers changes in bank conduct, Cease and desist orders in many cases follow Formal agreements and consequently have less strong impact on bank behaviour. Prompt corrective actions remain insignificant, reflecting the low number of these actions.

[TABLE 3: Main results]

What might underlie these findings? The additional tests in Table 3 report results on possible mechanisms through which bank regulatory actions might affect local economic growth. Panel B focuses on Total loan growth, and Panel $\mathrm{C}$ on growth in liquidity creation. We measure loan growth by aggregating bank-level data for total loans for each county-year. ${ }^{5}$ For the calculation of liquidity creation, we follow Berger and Bouwman (2009). ${ }^{6}$

\footnotetext{
Since loan volumes, unlike deposit data, are only available as aggregates for each individual bank rather than the individual branches, we estimate multimarket banks' amount of loans and liquidity creation in different counties as a proportion of the deposits shares held by these banks' branches in each county. First, we determine the share of each bank's total deposits held in each county. Next, we multiply the institution's loan and liquidity creation volumes by their deposit shares to obtain a breakdown of both lending and liquidity creation for each county and year. We finally aggregate lending and liquidity creation of each institution in a given county to obtain total county-year level loans and liquidity creation figures, and then calculate growth rates of these variables. Our approach is similar to the method proposed by Adams, Breevort, and Kiser (2007). They estimate the distribution of multimarket banks' accounts for MSAs and counties using deposit shares held by banks' branches.

6 Berger and Bouwman (2009) propose a three-step procedure to compute bank liquidity creation. First, using information on the category and maturity of banks' assets and liabilities, we classify bank assets, liabilities and equity as liquid, semi-liquid, or illiquid depending on ease, cost, and time it takes customers to obtain liquid funds from the bank in case of liability items, and based on ease, cost and time with which banks can dispose of their obligations in the case of assets. Second, we next assign weights of either $+1 / 2,0$, or $-1 / 2$ to all bank activities
} 
Loan growth decreases by 3.3 percentage points immediately after Severe actions, and liquidity creation contracts by 3.7 percentage points. These effects are again substantial. Moreover, considering that loan contractions capture only the lending dimension of bank activities and omit off-balance sheet activities and lines of credit that are typically drawn down during crises (Ivashina and Scharfstein, 2010), our use of the liquidity creation measure which captures bank intermediation activities more comprehensively suggests that only focusing on lending activities underestimates the effect enforcement actions have on bank output. While such actions are designed to restore bank health, a side-effect is a contraction in lending to the private sector, which leads to slowdowns in economic growth as it can stymie productive investments by financially constrained firms (Rajan and Zingales, 1998), and can depress competition for market share within the county-industry in locations where informationally opaque entrants represent an important determinant of productivity (Aghion et al., 2009).

Among the control variables, we find that increased demand for credit correlates positively with all three dependent variables in Table 3, whereas the structure of the banking market is only relevant for explaining loan growth and liquidity creation. Counties with larger firms tend to have higher growth rates, and we also observe a negative relationship between personal income growth and the rate of population growth. Personal income growth, loan growth, and liquidity creation tend to be lower during the crisis period.

\subsection{Robustness Tests}

This section offers four sensitivity checks.

Our first exercise empirically tests the parallel trends test assumption. While the illustration in Figure 4 suggests that treatment and control groups behave similarly in the years prior to the enforcement actions, we now offer some econometric backup using a falsification exercise. If contractions in growth rates precede enforcement actions, a simultaneous relationship will exist. In instances where there are pre-treatment trends within the county we would expect an artificial placebo treatment to have the same coefficient magnitude and significance as the one for the actual treatment dummy. Therefore, we now create placebo treatments and repeat our analysis assuming that the enforcement actions occurred two years prior to their actual occurrence. This test is based on the idea that the effects we uncovered above are causally related to the enforcement actions rather than some alternative factors. Table 4 reports the results.

The placebo actions are statistically indistinguishable from zero in Panel A, and they also remain insignificant in Panel B, suggesting that the observed changes in personal income growth, loan growth, and liquidity creation growth are indeed causally related to the enforcement actions.

[TABLE 4: Placebo regressions]

In the second and third robustness test, we rerun our regressions using two alternatively constructed control groups to adjust the tests for observable time-varying differences in growth opportunities that affect the convergence in growth rates (Huang, 2008).

classified in the first step. The weights correspond to liquidity creation theory, which asserts that banks create liquidity by converting illiquid assets into liquid liabilities, whilst by transforming liquid assets into illiquid liabilities or equity banks destroy liquidity. In the final step, we calculate how much liquidity each bank creates by combining and multiplying the activities classified in step 1 with the weights from step 2. Our measure of liquidity creation is the preferred measure from Berger and Bouwman (2009) which classifies all activities other than loans by both product category and maturity while loans are only classified based on category due to data availability constraints. We also include off-balance sheet items, so that our measure of liquidity creation is identical to the measure termed 'cat fat' by Berger and Bouwman (2009). 
The first determinant for differences in growth is the income gap. If treatment and control group counties vary substantially in terms of their pretreatment per capita income growth our coefficients could reflect discrepancies in income as growth rates in low income growth counties are likely to converge over time with the average growth rate. To account for instances in which the income gap between treatment and control group counties changes during our sample period in the same region, we match treatment counties with neighbouring counties adjacent within a 20 miles radius, and choose control group counties based on the difference in the mean pretreatment per capita personal income growth between the treatment county and the adjacent county. Additionally, we require the presence of at least on single market bank in the control group county, and we impose that no enforcement action in single market banks be observed in the neighbouring counties throughout the sample period. ${ }^{7}$

In this test, we include only one county with the smallest difference in income growth in the control group. Doing so reduces our sample from the initial 15,329 to 9,277 observations. However, this specification has the benefit that it provides a cleaner test of our hypothesis because it allows comparing the change in the dependent variables between the most similar regions in terms of similarities in income growth.

Our second test focuses on differences in growth opportunities which are determined by the composition of industry specific growth patterns on the regional level. For instance, if the industry structure in a county is dominated by low growth manufacturing companies while another county is characterised by high growth technology firms, differences in per capita personal income growth are likely to be observed even in the absence of enforcement actions. To adjust the regressions for the growth opportunity gap, we use as a second alternative control group counties that have the smallest growth opportunity gap, defined as the difference in manufacturing income share between the two counties at the beginning of the period, multiplied by the county-level growth rate difference between the manufacturing sector and the nonmanufacturing sector. We again impose the criteria of having at least one single market bank and that no enforcement action was observed in the control group county.

Table 5 presents the results. Irrespective of the type of matching strategy, our estimates confirm the previous inferences for the effect of Severe enforcement actions on personal income growth. On average, treatment group counties grow 0.6 percentage points lower compared to counties in the control group after adjusting for time-varying determinants of growth. ${ }^{8}$

\section{[TABLE 5: Alternative control group]}

We perform two additional tests to reflect on the possibility that enforcement actions might not occur randomly. If so, the non-random assignment can bias our coefficients as it gives rise to selection issues (Heckman, Ichimura, and Todd, 1997). To address this, we now exploit propensity score matching methods, and instrumental variable techniques.

\footnotetext{
To identify neighbor counties adjacent within 20 miles radius we use Allan Collard-Wexler's Adjacent County Data, available from: http://pages.stern.nyu.edu/ acollard/Data.html.

8 In further tests, we consider whether removing banks which received capital injections under the Troubled Asset Relief Programme (TARP) affects our inferences. The intuition is that TARP capital injections can bias our findings because there was a perception that TARP banks have a responsibility to lend (Ryan, 2008). We obtain virtually identical coefficients for our key variables. These tests are relegated to Appendix B. Additionally, we check whether multiple interventions in the same county amplify the effects. Appendix C contains regressions that exclude sequentially counties with multiple interventions in the same year, with multiple interventions across difference years, and with different types of interventions, but our key results remain very similar.
} 
Our tests are important to rule out that the results are driven by the composition of the treatment and control groups. It is critical to consider that whether single-market banks located in some counties are more likely to receive enforcement actions than other banks based on the structure of the local banking sector, e.g., its competitiveness, and the immediate economic environment.

Table 6 shows the results obtained with a nearest neighbour propensity score matching method. This method ensures we obtain the closest possible similarity between the characteristics of the treatment and control groups. ${ }^{9}$ We match counties based on bank market structure (HHI), population growth, and average firm size. Since matching techniques can be sensitive to the number of matches used, we report results using 2 and 4 matches.

The estimates in Table 6 indicate that our results are robust to this alternative estimation technique. We continue to find that Severe actions reduce the rate of economic growth, and this result obtains irrespective of the number of counties in the control group. However, the size of the treatment effect is now an order of magnitude greater than before. Counties that receive treatment grow 1.1 percentage points slower relative to the control group, suggesting that our previous results were biased downwards. Formal agreements as well as Cease and desist orders continue to exert a negative effect on growth in Panel A. One notable difference between the results in Table 6 relative to the findings presented in Table 4 is that Prompt corrective actions are now also significantly related to Personal income growth. This type of action reduces personal income growth by about 5.8 percentage points. Panels $\mathrm{B}$ and $\mathrm{C}$ that focus on the underlying mechanisms show that the coefficients are almost unchanged relative to those obtained from the DD estimator. The only exception is that Less severe actions now cause significant reductions in the growth of liquidity creation.

[TABLE 6: Propensity score matching methods]

So far we have demonstrated the exogeneity of treatment and the robustness of our results to controlling for non-random assignment. A concern is that owing to the structure of our data we are unable to account for time-varying, county-specific factors which may be contained in the error term but might also be coincident with treatment. Since the propensity score matching estimator cannot resolve this problem entirely, we investigate this matter further and adopt an instrumental variables approach to ensure our results are free of endogeneity bias. For this test, we use a two-stage estimator.

Our instrument set for the first stage, estimated using a linear probability model as in Dam and Koetter (2012), is chosen based on three key concepts: regulatory monitoring intensity, the idea

9 The propensity score matching method constructs control groups of counties which have a similar probability of having single-market banks that are subject to regulatory enforcement actions but no such event takes place. Specifically, the propensity score is defined as the probability of being subject to enforcement actions, conditional on pre-enforcement action characteristics. Our propensity score matching estimator computes the unobserved outcome for each county because we are faced with a problem of missing data. The idea is to estimate the untreated outcome for each country in the control group. Assuming that observing enforcement actions is random for counties that have similar characteristics prior to the action, the estimator calculates the average outcome of similar counties that do not have enforcement actions to estimate the untreated outcome. Thus, for each county in the control group, the estimator imputes the missing outcome by finding counties with similar characteristics that did not receive treatment. For instance, for every county that issued Severe Actions, the nearest-neighbour technique chooses untreated counties with propensity scores closest to the treatment county propensity score. Then, the estimator calculates an arithmetic average of the change in personal income growth, loan growth, and liquidity creation growth of these untreated counties. 
that information asymmetries about the banks' condition and transportation costs affect regulators' propensity to intervene, and the scope for political pressure banks can exert.

The first instrument is a Monitoring index that provides insights into regulatory monitoring intensity on the county level. This index is based on a dummy variable for each bank which takes on the value of one if the number of restatements of balance sheets and income statements triggered by regulatory monitoring is below the mean for all counties and years. The intuition is that enforcement actions are more likely to be issued against banks located in a county where more banks attempt to cover up financial mismanagement. To obtain the index, we aggregate this dummy for all banks on the county level for each year. We expect the index to enter the first stage regressions with a negative sign.

Our second instrument reflects information asymmetries and transportation costs. Flannery et al. (2013) show that interventions into banking systems are founded on the belief that they alleviate information asymmetries, and Berger et al. (2000) stress that only recent on-site inspections provide accurate information about the condition of a bank. Relatedly, Kedia and Rajgopal (2011) show that a resource constraint regulator can view travel cost as an impediment to the efficient allocation of investigative resources suggesting that geographically close on-site inspections are more efficient as they are both cheaper and regulators know more about banks located in close proximity due to less information asymmetries. We use Distance to FDIC as a proxy for information asymmetries and transportation costs. ${ }^{10} \mathrm{We}$ compute this variable as the average distance in miles between the regional FDIC headquarter and each bank in the county, and we anticipate an inverse relation between distance and enforcement actions. If regulators are, on average, more closely located to the banks, they have better information about their condition can are more likely to issue enforcement actions.

The third instrument interacts Distance to FDIC with Assessment fees for FDIC deposit insurance. FDIC deposit insurance fees are based on two components: the size of the institution and its riskiness. ${ }^{11}$ Since U.S. regulators have little scope for forbearance, we expect a positive effect of FDIC assessment fees and the probability to intervene as higher risk ratings also increase regulatory monitoring. For the interaction term, we also expect a positive coefficient in the first stage as the effect of FDIC assessments should outweigh the intervention-decreasing effect of distance.

In the second stage, we then use the estimated probabilities of enforcement actions to gauge their effect on the three dependent variables in Table 7. As we only have four instruments for the four endogenous variables we could not perform overidentification tests if we force all endogenous variables in the same equation. We therefore instrument each endogenous variable in a separate regression to also show the Hansen test.

[TABLE 7: Instrumental variable regressions]

We first discuss the instrumental variables estimates for income growth. We find support for our core hypothesis: Severe actions significantly reduce growth. The coefficient reported in Column 1 represents the upper bound of the effect of enforcement actions. The estimate is two

10 A number of studies argue that distance is a good proxy for the existence of information asymmetries and travel costs, e.g., Hau (2001) and Degryse and Ongena (2005).

11 The size component derives from the assessment base, defined as average consolidated total assets minus average tangible equity and the risk component reflects a combination of financial ratios and the CAMELS rating including whether the bank is classified as a large and highly complex institution. 
orders of magnitude greater compared to the baseline estimates from the DD estimator. This suggests that the omitted variables were positively correlated with treatment status.

For our instrumental variable approach to be valid, we require the instruments to be correlated with the endogenous variable, Severe actions, but to be uncorrelated with economic growth. The first stage results show that enforcement actions increase in the monitoring index, and the interaction term between FDIC assessment fees and distance to the regional FDIC office also enters positively. The effect of Distance to the FDIC seems moderated entirely via FDIC assessment fees in this regression. Importantly, the diagnostic tests reported at the bottom of Table 7 show the instruments are relevant. The Kleibergen-Paap F-Statistic on the excluded instruments indicates that they are strongly correlated with Severe actions. Our F-Statistic exceeds the critical value of 10 by far, and the Hansen overidentification test in Column 1 indicates that the assumption of instrument exogeneity is also satisfied. ${ }^{12}$

The effects of Formal agreements and Cease and desist orders on personal income growth are unaffected by the change in estimation methodology and the diagnostic tests confirm relevance and exogeneity of our instruments. The instrumental variable regressions which focus on loan growth and growth in liquidity creation yield similar patterns to the results we reported above.

\subsection{Extensions: Decomposing Bank Lending Behaviour}

Our main results reveal significant contractions in lending following enforcement actions. A question that naturally arises then is whether all lending categories are equally affected or whether banks differentiate by the types of borrowers when they decide to cut back their lending. ${ }^{13}$

Table 8 decomposes lending into loans to the agricultural sector, commercial and industrial loans, consumer, real estate loans, and loans to other depositories. We find a recurrent pattern. Severe actions reduce lending across all categories while Less severe actions have no effect. However, the magnitudes of the effects differ strongly. Loans to other depositories decline by 18.7 percentage points following Severe actions, while reductions to other lending categories are in the range between 2.0 and 4.3 percentage points. Since interbank lending is short-term and often overnight, these activities can be adjusted more quickly relative to other lending categories. Moreover, the bank that is subject to the enforcement action is also likely to reduce lending to other banks because of precautionary liquidity hoarding because it may be isolated in the interbank market, and this triggers liquidity hoarding.

The estimates in Panels A to D suggest that the effects of enforcement actions are similar, although commercial and industrial loans are more affected by such measures than real estate lending. The fact that commercial and industrial lending as well as consumer lending decline in the aftermath of enforcement actions suggests that the observed slowdown in growth is partly attributable to a reduction in the supply of credit to productive enterprise and consumer expenditure. Given the composition of lending, our estimates show that enforcement actions have a larger effect on total lending through the commercial and industrial lending channel $(0.97$ percentage point decrease compared with 0.36 percentage points for consumer lending). As the

12 Note that only in the case of Less severe actions (which remain insignificant throughout all analyses), we are a faced with a problem of weak instruments (Kleibergen-Paap F-Statistic: 9.53). Our instruments are always significant with the exception of regressions where we focus on 12 instances of Prompt corrective actions. The lack of significance in these tests reflects insufficient variation in the dependent variable in the first stage.

13 Appendix A provides an overview about the distribution of bank lending activities across different loan categories broken down by the type of borrowers. 
mean total loans growth rate is $5.4 \%$, the size of these effects is substantial. By far the most important channel through which regulatory actions affect lending is real estate lending. Here, we find a Severe action to decrease total lending in the county by 1.18 percentage points. In view of the housing bubble and the sustained effect this had on consumption during the sample period, we believe that part of the explanation underlying the relation between enforcement actions and personal income growth is driven by the effect these actions have on real estate lending.

Table 8 also shows a breakdown by different types of Severe actions. Column 2 indicates that by far the strongest effect for declines in lending is due to Cease and desist orders with the exception of Panel E. For lending to other depositories, Formal agreements have the strongest effect, and they also cause reductions in commercial and industrial lending.

[TABLE 8: Effects of enforcement actions on different lending categories]

\section{Concluding Remarks}

The key result in this paper suggests that regulatory enforcement actions on banks trigger adverse effects for the real economy.

Using DD estimations, controlling for credit demand conditions, and accounting for the nonrandom assignment of regulatory enforcement actions, we robustly document that Severe enforcement actions such as Formal agreements and Cease and desist orders imposed on singlemarket banks reduce personal income growth rates by 0.7 and 0.4 percentage points, respectively. With growth rates averaging $1.1 \%$ between 2001 and 2009 on the county level in the U.S., these effects are substantial in terms of their economic magnitude. Our more detailed analyses illustrate that the reduction in growth is brought about by declines in bank lending, in particular commercial and industrial, and real estate lending, and in banks' liquidity creation. Clearly, these enforcement actions constitute shocks to banks' intermediation activities that spill over into the real economy.

Our research builds on a quickly evolving body of literature that homes in on the potentially unintended effects of regulatory enforcement actions on distressed banks for the real economy. Unlike other studies that limit their analyses to the effects of enforcement actions to the micro level and focus exclusively on bank behaviour, the main innovation in our article is that we are the first to show that local economic growth is causally affected by these regulatory interventions. Crucially, our dataset that contains information on branches from both single-market and multimarket banks operating in the same counties as the banks that are subject to regulatory actions allows us to compute aggregates of bank lending and liquidity creation to establish how these aggregates behave prior to and following enforcement actions. Exploiting the information about the presence of branches of multi-market banks, we are able to test for and rule out that substitution effects of lending and liquidity creation activities between single-market and multimarket banks exist that would undermine the relationship we uncover. Our empirical framework, therefore, is uniquely suited to highlight this important macro-financial linkage: While enforcement actions are undoubtedly important to restore bank health, they also have potential to trigger considerable reductions in economic growth. 


\section{References}

Adams, R. M., K. P. Brevoort, and E. K. Kiser (2007) 'Who competes with whom? The case of depository institutions', Journal of Industrial Economics, Vol. 55, pp. 141-167.

Aghion, P., Blundell, R., Griffith, R., Howitt, P., and S. Prantl (2009) 'The effects of entry on incumbent innovation and productivity', Review of Economics and Statistics, Vol. 91, pp. 20-32.

Ashcraft, A. B. (2005) 'Are banks really special? New evidence from the FDIC-induced failure of healthy banks', American Economic Review, Vol. 95, pp. 1712-1730.

Berger, A. N., and C. H. S. Bouwman (2009) 'Bank liquidity creation', Review of Financial Studies, Vol. 22, pp. 3779-3837.

Berger, A. N., C. H. S. Bouwman, T. Kick, and K. Schaeck (2012) 'Bank risk taking and liquidity creation following regulatory interventions and capital support', Discussion Paper 2011-088, Tilburg University CentER.

Berger, A. N., S. M. Davies, and M. J. Flannery (2000) 'Comparing market and supervisory assessments of bank performance: Who knows what when?' Journal of Money, Credit and Banking, Vol. 32, pp. 641-667.

Bernanke, B. B. (1983) 'Nonmonetary effects of the financial crisis in the propagation of the Great Depression', American Economic Review, Vol. 73, pp. 257-276.

Black, S. E., and P. E. Strahan (2002) 'Entrepreneurship and bank credit availability', Journal of Finance, Vol., 57, pp. 2807-2833.

Calomiris, C. W., and J. R. Mason (2003) 'Consequences of bank distress during the great depression', American Economic Review, Vol. 93, pp. 937-947.

Cetorelli, N., and P. E. Strahan (2006) 'Finance as a barrier to entry: Bank competition and industry structure in local U.S. markets', Journal of Finance, Vol. 61, pp. 437-461, 02.

Chava, S., and A. Purnanandam (2011) 'The effect of banking crises on bank-dependent borrowers', Journal of Financial Economics, Vol. 99, pp. 116-135.

Curry, T. J., J. P. O'Keefe, J. Coburn, and Ly. Montgomery (1999) 'Financially distressed banks: How effective are enforcement actions in the supervision process?', FDIC Banking Review, Vol. 12, pp. 118.

Dam, L., and M. Koetter (2012) 'Bank bailouts and moral hazard: Empirical evidence from Germany', Review of Financial Studies, Vol. 25, pp. 2343-2380.

Degryse, H., and S. Ongena (2005) 'Distance, lending relationships, and competition', Journal of Finance, Vol. 60, pp. 231-266.

Diamond, D. W. (1984) 'Financial intermediation and delegated monitoring', Review of Economic Studies, Vol. 51, pp. 393-414.

Felici, R., and M. Pagnini (2008) 'Distance, bank heterogeneity and entry in local banking markets', Journal of Industrial Economics, Vol. 56, pp. 500-534

Flannery, M. J., S. H. Kwan, and M. Nimalendran (2013) The 2007-2009 financial crisis and bank opaqueness', Journal of Financial Intermediation, Vol. 22, pp. 55-84.

Gan, J. (2007) 'The real effects of asset market bubbles: Loan- and firm-level evidence of a lending channel', Review of Financial Studies, Vol. 20, pp. 1941-1973.

Gibson, M. S. (1995) 'Can bank health affect investment? Evidence from Japan', Journal of Business, Vol. 68, pp. 281-308.

Hau, H. (2001) 'Location matters: An examination of trading profits', Journal of Finance, Vol. 56, pp. 1959-1983.

Heckman, J. J., H. Ichimura, and P. Todd (1997) 'Matching as an econometric evaluation estimator: Evidence from evaluating a job training programme', Review of Economic Studies, Vol. 64, pp. 60554. 
Huang, R. (2008) 'The real effect of bank branching deregulation: Comparing contiguous counties across U.S. state borders', Journal of Financial Economics, Vol.87, pp. 678-705.

Ioannidou, V. P. (2008) 'Does monetary policy affect the central bank's role in bank supervision?' Journal of Financial Intermediation, Vol. 14 (2005) 58-85.

Ivashina, V., and D. S. Scharfstein (2010) 'Bank lending during the financial crisis of 2008', Journal of Financial Economics, Vol. 97, pp. 319-338.

James, C. (1987) 'Some evidence on the uniqueness of bank loans', Journal of Financial Economics, Vol. $19,217-235$.

Kang, J.-K., and R. M. Stulz (2005) 'Do banking shocks affect borrowing firm performance? An analysis of the Japanese experience', Journal of Business, Vol. 73, pp. 1-23.

Kedia, S., and S. Rajgopal (2011) 'Do the SEC's enforcement preferences affect corporate misconduct?', Journal of Accounting and Economics, Vol. 51, pp. 259-278.

Khwaja, A. I., and A. Mian (2008) 'Tracing the impact of bank liquidity shocks: Evidence from an emerging market', American Economic Review, Vol. 98, pp. 1413-1442.

Lemmon, M. and M. R. Roberts (2010) 'The response of corporate financing and investment to changes in the supply of credit', Journal of Financial and Quantitative Analysis, Vol. 45, pp. 555-587.

Mailath, G. J., and L. J. Mester (1994) 'A positive analysis of bank closure', Journal of Financial Intermediation, Vol. 3, pp. 272-299.

Ongena, S., D. C. Smith, and D. Michalsen (2003) 'Firms and their distressed banks: Lessons from the Norwegian banking crisis', Journal of Financial Economics, Vol. 67, pp. 81-112

Peek, J., and E. S. Rosengren (1996) 'Bank regulatory agreements and real estate lending', Real Estate Economics, Vol. 24, pp. 55-73.

Peek, J., and E. S. Rosengren (1995) 'Bank regulation and the credit crunch', Journal of Banking and Finance, Vol. 19, pp. 679-692.

Ryan, A.W. (2008) Remarks at the Securities Industry and Financial Markets Association (SIFMA) annual meeting. October 28. New York.

Schnabl, P. (2012) 'The international transmission of bank liquidity shocks: Evidence from an emerging market', Journal of Finance, Vol. 67, pp. 897-932.

Slovin, M. B., M. E. Sushka, and J. A. Polonchek (1993) 'The value of bank durability: Borrowers as bank stakeholders', Journal of Finance, Vol. 48, pp. 247-66. 
Appendix A: Summary Statistics for Loan Categories

\begin{tabular}{|c|c|c|c|c|c|}
\hline Year & $\begin{array}{c}\text { Agricultural } \\
\text { Production Loans }\end{array}$ & $\begin{array}{l}\text { Commercial and } \\
\text { Industrial Loans } \\
\end{array}$ & $\begin{array}{c}\text { Consumer } \\
\text { Loans } \\
\end{array}$ & $\begin{array}{c}\text { Real Estate } \\
\text { Loans }\end{array}$ & $\begin{array}{c}\text { Loans to other } \\
\text { Depository Institutions }\end{array}$ \\
\hline & (\% of total loans) & (\% of total loans) & (\% of total loans) & (\% of total loans) & (\% of total loans) \\
\hline 2001 & 1.54 & 27.17 & 15.95 & 52.01 & 3.33 \\
\hline 2002 & 1.37 & 23.61 & 16.05 & 55.61 & 3.36 \\
\hline 2003 & 1.28 & 21.40 & 16.75 & 56.95 & 3.62 \\
\hline 2004 & 1.23 & 20.61 & 16.74 & 58.16 & 3.26 \\
\hline 2005 & 1.18 & 21.37 & 15.50 & 58.55 & 3.40 \\
\hline 2006 & 1.17 & 21.81 & 12.89 & 62.01 & 2.11 \\
\hline 2007 & 1.12 & 23.31 & 12.76 & 61.04 & 1.78 \\
\hline 2008 & 1.12 & 23.42 & 12.84 & 61.31 & 1.31 \\
\hline 2009 & 1.15 & 19.79 & 13.30 & 64.61 & 1.16 \\
\hline Average & 1.24 & 22.50 & 14.75 & 58.92 & 2.59 \\
\hline
\end{tabular}

Notes. This table presents statistics for the distribution of lending. Types of loans are scaled by total loans in a given year. Total loans is the sum of loans to agricultural production, commercial and industrial loans, construction loans, real estate loans (both commercial and residential), and loans to other depository institutions. We exclude loans of depository institutions located in Delaware and South Dakota states. 
Appendix B: Additional Robustness Test (TARP Banks Excluded)

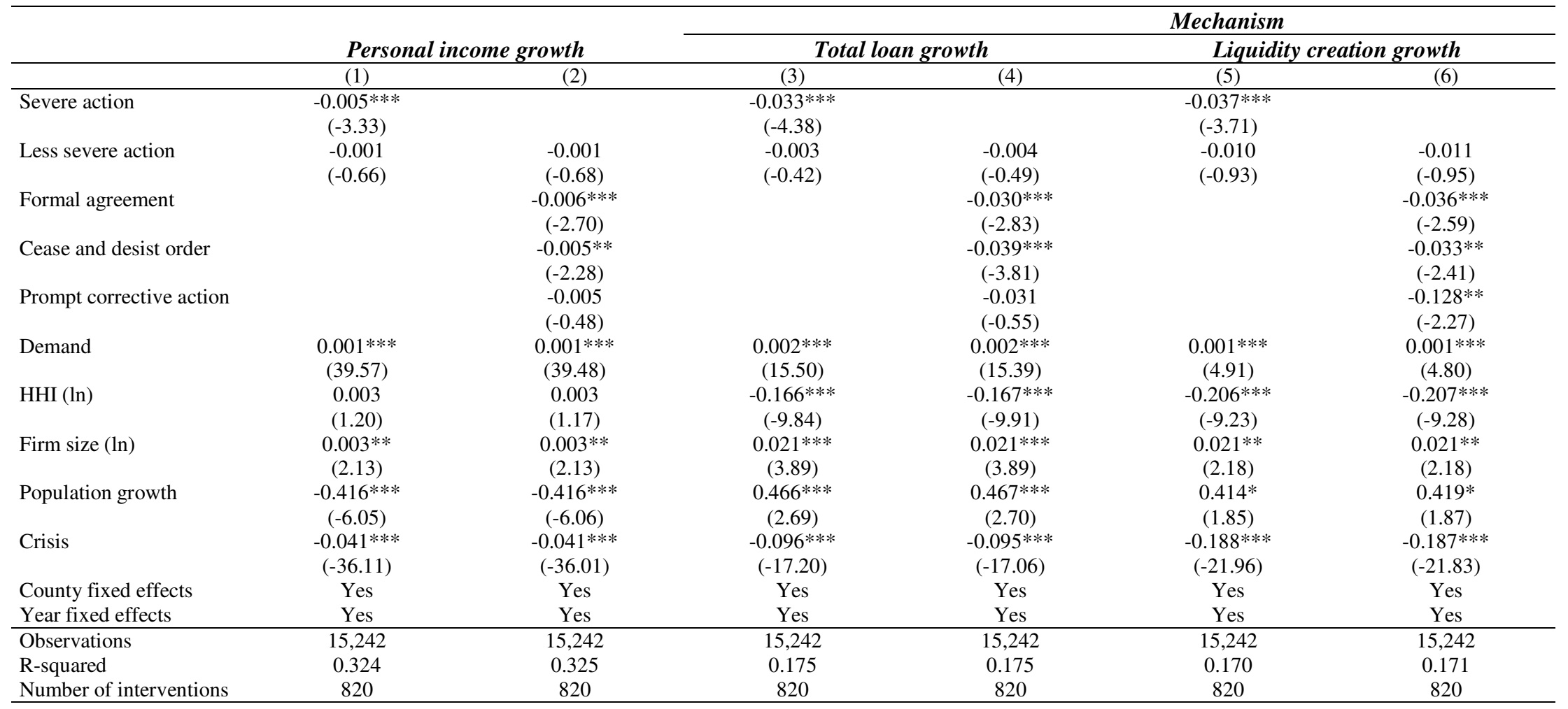

Notes. This table presents results of difference-in-difference regressions of enforcement actions in single-market banks on per capita personal income growth on the county level, and we also explore the underlying mechanism by analyzing total loan growth, and liquidity creation growth. The sample excludes banks that received capital injections from the CPP of the TARP. Enforcement actions include Severe actions (dummy variable equal to 1 if Formal agreements, Cease and desist order, and/or Prompt corrective action is observed and zero otherwise); Less severe action is a dummy variable equal to 1 if enforcement actions against Personnel and individuals, Formal memoranda of understanding, Hearing notices, Sanctions due to HMDA violation or/and other actions and fines are observed, or zero otherwise). Formal agreements is a dummy variable equal to 1 if formal agreement is observed and zero otherwise; Cease and desist orders is a dummy variable equal to 1 if Cease and desist orders are observed and zero otherwise; Prompt corrective actions is a dummy variable equal to 1 if Prompt corrective action is observed and zero otherwise. Our regressions control for demand for credit (Demand), concentration of the local banking market, measured by a county-level deposit-based Herfindahl-Hirschman Index (HHI), average firm size in the county (Firm size), population growth (Population), and the effect of the current financial crisis years (dummy variable equal to 1 for the years 2007, 2008, 2009 and zero otherwise. Delaware and South Dakota counties excluded. We report robust tstatistics in parentheses, and errors are clustered on the county level. *** $\mathrm{p}<0.01, * * \mathrm{p}<0.05,{ }^{*} \mathrm{p}<0.1$. 
Appendix C: Additional Robustness Test (Accounting for Multiple Interventions)

\begin{tabular}{|c|c|c|c|c|c|c|}
\hline \multicolumn{7}{|c|}{ Panel A: Counties with multiple interventions in the same year excluded } \\
\hline & \multirow{2}{*}{\multicolumn{2}{|c|}{ Personal income growth }} & \multicolumn{4}{|c|}{ Mechanism } \\
\hline & & & \multicolumn{2}{|c|}{ Total loan growth } & \multicolumn{2}{|c|}{ Liquidity creation growth } \\
\hline & $(1)$ & $(2)$ & (3) & $(4)$ & $(5)$ & $(6)$ \\
\hline Severe action & $\begin{array}{c}-0.004 * * \\
(-2.46)\end{array}$ & & $\begin{array}{c}-0.029 * * * \\
(-3.52)\end{array}$ & & $\begin{array}{c}-0.037 * * * \\
(-3.26)\end{array}$ & \\
\hline Less severe action & $\begin{array}{l}-0.001 \\
(-0.37)\end{array}$ & $\begin{array}{l}-0.001 \\
(-0.35)\end{array}$ & $\begin{array}{l}-0.003 \\
(-0.42)\end{array}$ & $\begin{array}{l}-0.003 \\
(-0.42)\end{array}$ & $\begin{array}{l}-0.009 \\
(-0.74)\end{array}$ & $\begin{array}{l}-0.009 \\
(-0.73)\end{array}$ \\
\hline Formal agreement & & $\begin{array}{c}-0.005^{*} \\
(-1.80)\end{array}$ & & $\begin{array}{c}-0.022^{*} \\
(-1.91)\end{array}$ & & $\begin{array}{c}-0.028^{*} \\
(-1.77)\end{array}$ \\
\hline Cease and desist order & & $\begin{array}{l}-0.003 \\
(-1.27)\end{array}$ & & $\begin{array}{c}-0.034 * * * \\
(-2.89)\end{array}$ & & $\begin{array}{c}-0.031 * * \\
(-1.99)\end{array}$ \\
\hline Prompt corrective action & & $\begin{array}{l}-0.014 \\
(-1.01)\end{array}$ & & $\begin{array}{l}-0.004 \\
(-0.04)\end{array}$ & & $\begin{array}{c}-0.146^{* * *} \\
(-2.08)\end{array}$ \\
\hline Control variables & Yes & Yes & Yes & Yes & Yes & Yes \\
\hline County fixed effects & Yes & Yes & Yes & Yes & Yes & Yes \\
\hline Year fixed effects & Yes & Yes & Yes & Yes & Yes & Yes \\
\hline Observations & 14,853 & 14,853 & 14,853 & 14,853 & 14,853 & 14,853 \\
\hline R-squared & 0.324 & 0.324 & 0.177 & 0.177 & 0.171 & 0.171 \\
\hline Number of interventions & 681 & 679 & 681 & 679 & 681 & 679 \\
\hline \multicolumn{7}{|c|}{ Panel B: Counties with multiple interventions in different years excluded } \\
\hline & & & \multicolumn{4}{|c|}{ Mechanism } \\
\hline & \multicolumn{2}{|c|}{ Personal income growth } & \multicolumn{2}{|c|}{ Total loan growth } & \multicolumn{2}{|c|}{ Liquidity creation growth } \\
\hline & $(1)$ & $(2)$ & (3) & $(4)$ & $(5)$ & $(6)$ \\
\hline Severe action & $\begin{array}{c}-0.006 * * \\
(-2.09)\end{array}$ & & $\begin{array}{c}-0.036^{* * * *} \\
(-2.82)\end{array}$ & & $\begin{array}{c}-0.045^{* *} \\
(-2.49)\end{array}$ & \\
\hline Less severe action & $\begin{array}{l}-0.001 \\
(-0.19)\end{array}$ & $\begin{array}{l}-0.001 \\
(-0.19)\end{array}$ & $\begin{array}{l}-0.006 \\
(-0.58)\end{array}$ & $\begin{array}{l}-0.006 \\
(-0.58)\end{array}$ & $\begin{array}{l}-0.023 \\
(-1.38)\end{array}$ & $\begin{array}{l}-0.023 \\
(-1.38)\end{array}$ \\
\hline Formal agreement & & $\begin{array}{l}-0.006 \\
(-1.58)\end{array}$ & & $\begin{array}{l}-0.024 \\
(-1.45)\end{array}$ & & $\begin{array}{l}-0.037 \\
(-1.62)\end{array}$ \\
\hline Cease and desist order & & $\begin{array}{l}-0.005 \\
(-1.22)\end{array}$ & & $\begin{array}{c}-0.043 * * \\
(-2.32)\end{array}$ & & $\begin{array}{l}-0.045 \\
(-1.59)\end{array}$ \\
\hline Prompt corrective action & & $\begin{array}{l}-0.012 \\
(-0.74)\end{array}$ & & $\begin{array}{c}-0.136 * * * \\
(-3.91)\end{array}$ & & $\begin{array}{l}-0.079 \\
(-0.75)\end{array}$ \\
\hline Control variables & Yes & Yes & Yes & Yes & Yes & Yes \\
\hline County fixed effects & Yes & Yes & Yes & Yes & Yes & Yes \\
\hline Year fixed effects & Yes & Yes & Yes & Yes & Yes & Yes \\
\hline Observations & 12,904 & 12,904 & 12,904 & 12,904 & 12,904 & 12,904 \\
\hline R-squared & 0.323 & 0.323 & 0.178 & 0.179 & 0.172 & 0.172 \\
\hline Number of interventions & 274 & 274 & 274 & 274 & 274 & 274 \\
\hline
\end{tabular}

Panel C: Counties with multiple types of interventions excluded

\begin{tabular}{|c|c|c|c|c|c|c|}
\hline & \multirow{2}{*}{\multicolumn{2}{|c|}{ Personal income growth }} & \multicolumn{4}{|c|}{ Mechanism } \\
\hline & & & \multicolumn{2}{|c|}{ Total loan growth } & \multicolumn{2}{|c|}{ Liquidity creation growth } \\
\hline & (1) & $(2)$ & (3) & (4) & (5) & $(6)$ \\
\hline Severe action & $\begin{array}{c}-0.005 * * * \\
(-2.85)\end{array}$ & & $\begin{array}{c}-0.039 * * * \\
(-4.75)\end{array}$ & & $\begin{array}{c}-0.045 * * * \\
(-4.12)\end{array}$ & \\
\hline Less severe action & $\begin{array}{l}-0.001 \\
(-0.33)\end{array}$ & $\begin{array}{l}-0.001 \\
(-0.34)\end{array}$ & $\begin{array}{l}0.002 \\
(0.20)\end{array}$ & $\begin{array}{l}0.001 \\
(0.17)\end{array}$ & $\begin{array}{l}-0.006 \\
(-0.47)\end{array}$ & $\begin{array}{l}-0.006 \\
(-0.49)\end{array}$ \\
\hline Formal agreement & & $\begin{array}{c}-0.005 * * \\
(-2.02)\end{array}$ & & $\begin{array}{c}-0.034 * * * \\
(-3.04)\end{array}$ & & $\begin{array}{c}-0.042 * * * \\
(-2.83)\end{array}$ \\
\hline Cease and desist order & & $\begin{array}{c}-0.005^{* *} \\
(-2.14)\end{array}$ & & $\begin{array}{c}-0.048 * * * \\
(-4.33)\end{array}$ & & $\begin{array}{c}-0.045 * * * \\
(-3.09)\end{array}$ \\
\hline Prompt corrective action & & $\begin{array}{l}0.001 \\
(0.04)\end{array}$ & & $\begin{array}{l}0.027 \\
(0.25)\end{array}$ & & $\begin{array}{c}-0.232^{* *} * \\
(-2.06)\end{array}$ \\
\hline Control variables & Yes & Yes & Yes & Yes & Yes & Yes \\
\hline County fixed effects & Yes & Yes & Yes & Yes & Yes & Yes \\
\hline Year fixed effects & Yes & Yes & Yes & Yes & Yes & Yes \\
\hline Observations & 12,904 & 12,904 & 12,904 & 12,904 & 12,904 & 12,904 \\
\hline R-squared & 0.323 & 0.323 & 0.178 & 0.179 & 0.172 & 0.172 \\
\hline Number of interventions & 274 & 274 & 274 & 274 & 274 & 274 \\
\hline
\end{tabular}

Notes. This table presents results of difference-in-difference regressions of placebo enforcement actions in single-market banks on per capita personal income growth on the county level, and we also explore the mechanisms by investigating total loan growth, and liquidity creation growth. In Panel A we exclude from treatment group counties in which more than one single-market banks has been issued with enforcement action in the same year. In Panel B, we exclude counties in which enforcement actions in single-market banks occur more than once during the sample period. Panel $\mathrm{C}$ shows results for sample which excludes counties in which more than one type of enforcement action is issued in the same year. All control variables reported in Table 3 are also included. Delaware and South Dakota counties excluded. We report robust t-statistics in parentheses, and errors are clustered on the county level. *** $\mathrm{p}<0.01, * * \mathrm{p}<0.05, * \mathrm{p}<0.1$. 
Table 1

Descriptive statistics for enforcement actions

\section{Panel A: Time distribution of enforcement actions in U.S. counties}

\begin{tabular}{|c|c|c|c|c|c|c|}
\hline \multirow{2}{*}{ Year } & \multirow{2}{*}{ Any action } & \multirow{2}{*}{ Severe actions } & \multirow{2}{*}{ Less severe actions } & \multicolumn{3}{|c|}{ Breakdown of Severe actions } \\
\hline & & & & Formal agreements & Cease and desist orders & Prompt corrective actions \\
\hline 2001 & 85 & 47 & 38 & 28 & 21 & 2 \\
\hline 2002 & 71 & 51 & 20 & 24 & 28 & 1 \\
\hline 2003 & 80 & 46 & 34 & 19 & 28 & 1 \\
\hline 2004 & 81 & 46 & 35 & 22 & 25 & 0 \\
\hline 2005 & 79 & 30 & 49 & 15 & 15 & 0 \\
\hline 2006 & 74 & 24 & 50 & 12 & 12 & 0 \\
\hline 2007 & 83 & 35 & 48 & 8 & 27 & 0 \\
\hline 2008 & 98 & 56 & 42 & 28 & 34 & 0 \\
\hline 2009 & 177 & 132 & 45 & 53 & 92 & 8 \\
\hline Total & 828 & 467 & 361 & 209 & 282 & 12 \\
\hline \multicolumn{7}{|c|}{ Panel B: Correlations between enforcement actions } \\
\hline & & Severe actions & Less severe actions & Formal agreements & Cease and desist orders & Prompt corrective actions \\
\hline Severe & & 1 & & & & \\
\hline Less se & & $\begin{array}{c}-0.028 * * * \\
(0.00)\end{array}$ & 1 & & & \\
\hline Formal & & $\begin{array}{c}0.663 * * * \\
(0.00)\end{array}$ & $\begin{array}{c}-0.018 * * \\
(0.02)\end{array}$ & 1 & & \\
\hline Cease a & rders & $\begin{array}{c}0.772 * * * \\
(0.00)\end{array}$ & $\begin{array}{c}-0.021 * * * \\
(0.00)\end{array}$ & $\begin{array}{c}0.101 * * * \\
(0.00)\end{array}$ & 1 & \\
\hline Prompt & actions & $\begin{array}{c}0.158 * * * \\
(0.00)\end{array}$ & $\begin{array}{l}-0.004 \\
(0.59)\end{array}$ & $\begin{array}{c}0.097 * * * \\
(0.00)\end{array}$ & $\begin{array}{c}0.100 * * * \\
(0.00)\end{array}$ & 1 \\
\hline
\end{tabular}


Table 2

\begin{tabular}{|c|c|c|c|c|c|c|}
\hline Variable & Observations & Mean & S.D. & Min & Max & Source \\
\hline \multicolumn{7}{|l|}{ Dependent variables } \\
\hline Real per capita personal income growth & 15329 & 0.011 & 0.034 & -0.051 & 0.082 & U.S. Bureau of Economic Analysis \\
\hline Liquidity creation growth & 15329 & 0.091 & 0.208 & -0.279 & 0.620 & SNL Financial, authors' calculation \\
\hline Total loans growth & 15329 & 0.054 & 0.134 & -0.215 & 0.405 & SNL Financial, authors' calculation \\
\hline Agricultural production loans & 15267 & 0.031 & 0.211 & -0.372 & 0.615 & SNL Financial, authors' calculation \\
\hline Commercial and industrial loans growth & 15329 & 0.036 & 0.186 & -0.313 & 0.489 & SNL Financial, authors' calculation \\
\hline Construction loans growth & 15329 & 0.005 & 0.169 & -0.309 & 0.456 & SNL Financial, authors' calculation \\
\hline Real estate loans growth & 15329 & 0.073 & 0.154 & -0.213 & 0.486 & SNL Financial, authors' calculation \\
\hline Loans to other depository institutions growth & 10738 & 0.317 & 1.551 & -0.990 & 6.130 & SNL Financial, authors' calculation \\
\hline \multicolumn{7}{|l|}{ Interventions } \\
\hline Severe actions & 15329 & 0.030 & 0.172 & 0 & 1 & SNL Financial, authors' calculation \\
\hline Less severe actions & 15329 & 0.024 & 0.152 & 0 & 1 & SNL Financial, authors' calculation \\
\hline Formal agreements & 15329 & 0.014 & 0.116 & 0 & 1 & SNL Financial \\
\hline Cease and desist orders & 15329 & 0.018 & 0.134 & 0 & 1 & SNL Financial \\
\hline Prompt corrective actions & 15329 & 0.001 & 0.028 & 0 & 1 & SNL Financial \\
\hline \multicolumn{7}{|l|}{ Control variables } \\
\hline Demand & 15329 & -15.747 & 30.347 & -53.225 & 34.400 & FED Senior loan officer survey \\
\hline HHI deposits (ln) & 15329 & -1.418 & 0.498 & -3.157 & 0.000 & SNL Financial, authors' calculation \\
\hline Firm size $(\ln )$ & 15329 & 2.522 & 0.590 & -1.386 & 4.580 & Bureau of Labor Statistics \\
\hline Population growth & 15329 & 0.005 & 0.015 & -0.534 & 0.151 & U.S. Bureau of Economic Analysis \\
\hline Crisis & 15329 & 0.300 & 0.459 & 0 & 1 & Authors' calculation \\
\hline
\end{tabular}

Notes. The table presents summary statistics, means, standard deviations, minima, maxima and the data sources. 
Table 3

Difference-in-difference regressions: The effect of enforcement actions

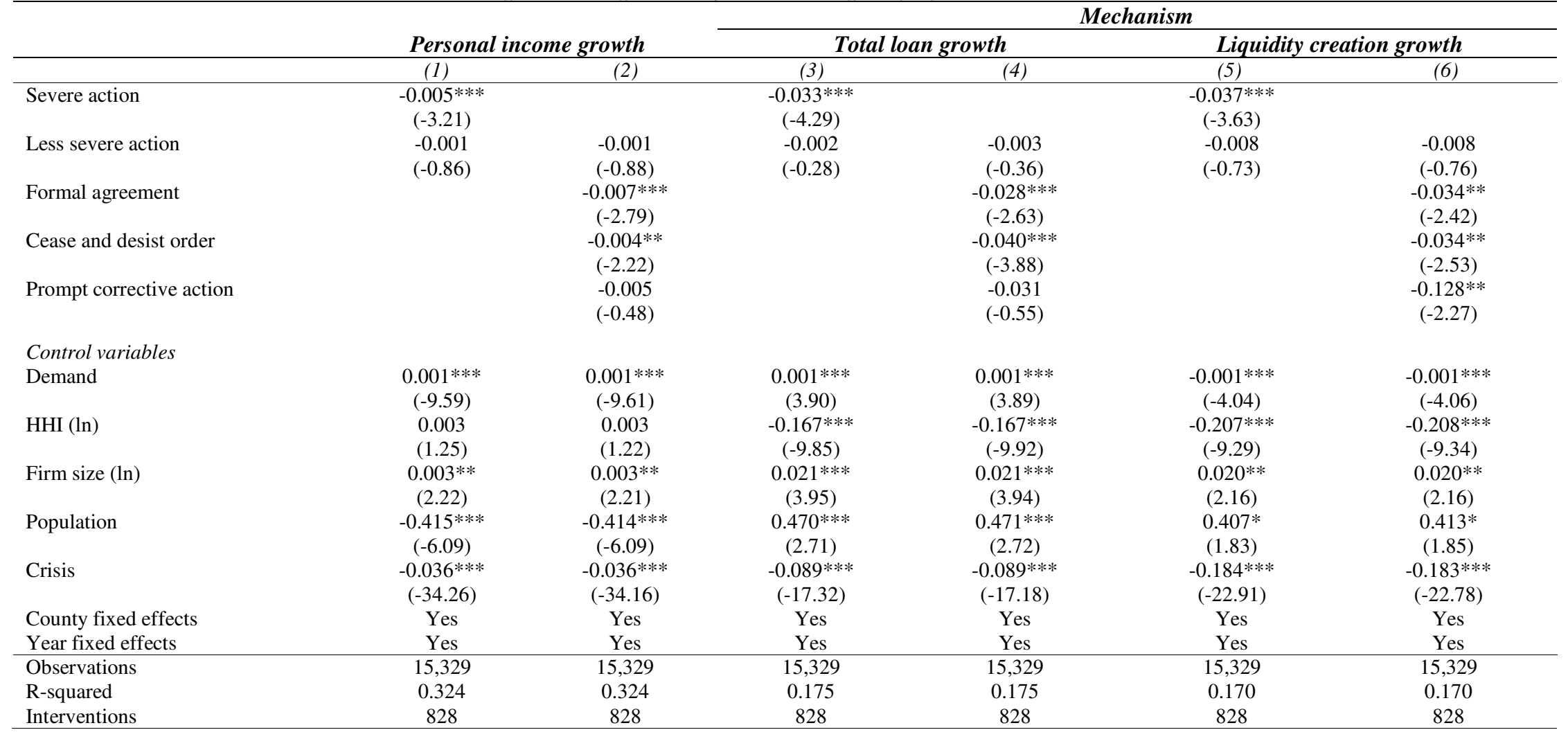

Notes. This table presents results of difference-in-difference regressions of enforcement actions in single-market banks on per capita personal income growth on the county level (Panel A), total loan growth (Panel B), and liquidity creation growth (Panel C). Enforcement actions include Severe actions (dummy variable equal to 1 if Formal agreements, Cease and desist order, and/or Prompt corrective action is observed and zero otherwise); Less severe action is a dummy variable equal to 1 if enforcement actions against Personnel and individuals, Formal memoranda of understanding, Hearing notices, Sanctions due to HMDA violation or/and other actions and fines are observed, or zero otherwise). Formal agreements is a dummy variable equal to 1 if formal agreement is observed and zero otherwise; Cease and desist orders is a dummy variable equal to 1 if Cease and desist orders are observed and zero otherwise; Prompt corrective actions is a dummy variable equal to 1 if Prompt corrective action is observed and zero otherwise. Our regressions control for demand for credit (Demand), concentration of the local banking market, measured by a county-level deposit-based Herfindahl-Hirschman Index (HHI), average firm size in the county (Firm size), population growth (Population), and the effect of the current financial crisis years (dummy variable equal to 1 for the years 2007 , 2008, 2009 and zero otherwise. Delaware and South Dakota counties excluded. We report robust t-statistics in parentheses, and errors are clustered on the county level. $* * * \mathrm{p}<0.01, * * \mathrm{p}<0.05, * \mathrm{p}<0.1$. 
Table 4

Placebo regressions: The effect of enforcement actions

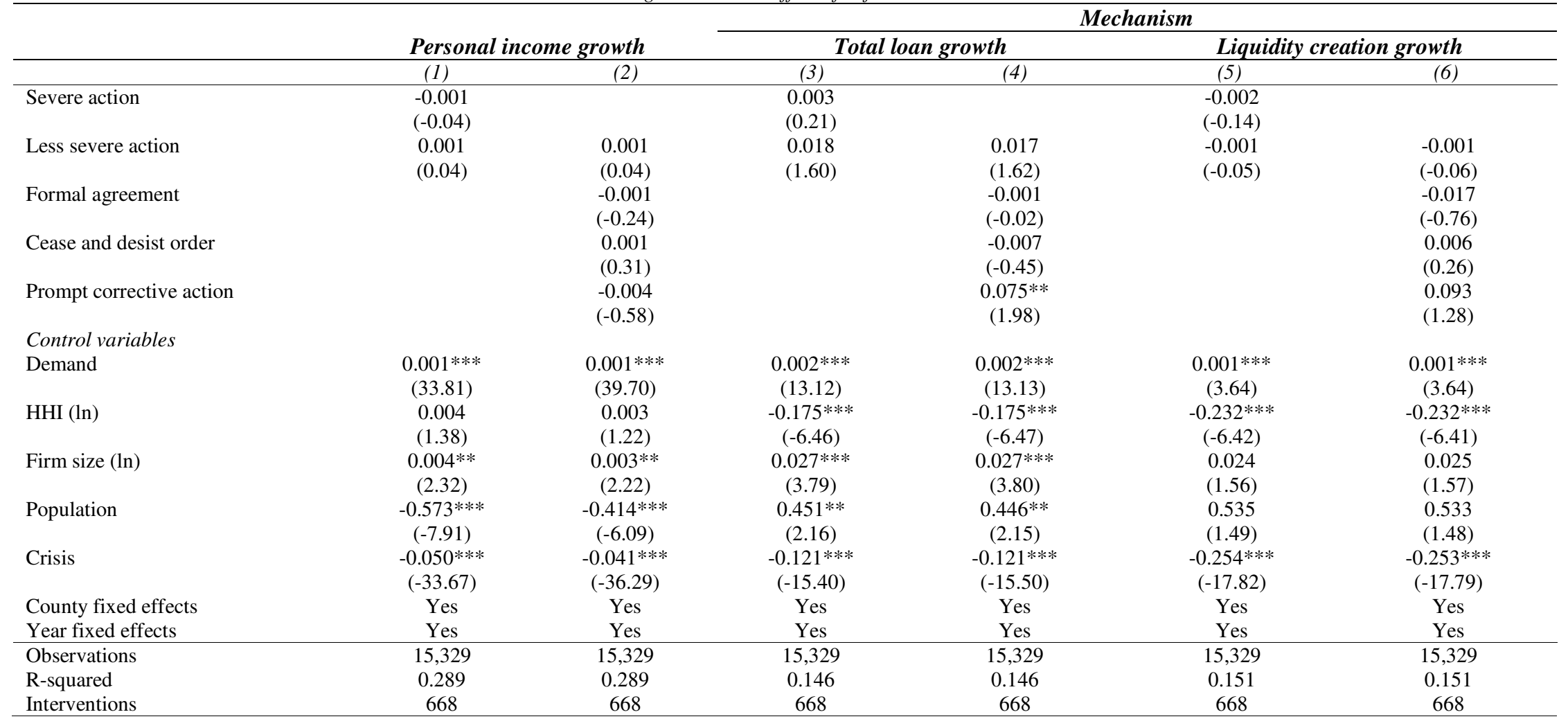

Notes. This table presents results of difference-in-difference regressions of placebo enforcement actions in single-market banks on per capita personal income growth on the county level (Panel A), total loan growth (Panel B), and liquidity creation growth (Panel C). We create placebo treatments by assuming that the enforcement actions occurred two years prior to their actual occurrence, their coding follows the exposition reported above in the notes to Table 3 . All control variables reported in Table 3 are also included. Delaware and South Dakota counties excluded. We report robust t-statistics in parentheses, and errors are clustered on the county level. *** $\mathrm{p}<0.01, * * \mathrm{p}<0.05, * \mathrm{p}<0.1$ 
Table 5

Robustness tests: Alternative control groups - convergence and spillover effects

\begin{tabular}{|c|c|c|c|c|c|c|c|c|c|c|c|c|}
\hline & & & & & \multicolumn{8}{|c|}{ Mechanism } \\
\hline & \multicolumn{4}{|c|}{ Personal income growth } & \multicolumn{4}{|c|}{ Total loan growth } & \multicolumn{4}{|c|}{ Liquidity creation growth } \\
\hline & (1a) & $(1 b)$ & $(2 a)$ & $(2 b)$ & $(3 a)$ & $(3 b)$ & $(4 a)$ & $(4 b)$ & $(5 a)$ & $(5 b)$ & (6a) & $(6 b)$ \\
\hline Control group matched on & $\begin{array}{c}\text { Income } \\
\text { growth gap }\end{array}$ & $\begin{array}{l}\text { Opportunity } \\
\text { growth gap }\end{array}$ & $\begin{array}{c}\text { Income } \\
\text { growth gap }\end{array}$ & $\begin{array}{l}\text { Opportunity } \\
\text { growth gap }\end{array}$ & $\begin{array}{c}\text { Income } \\
\text { growth gap }\end{array}$ & $\begin{array}{l}\text { Opportunity } \\
\text { growth gap }\end{array}$ & $\begin{array}{c}\text { Income } \\
\text { growth gap }\end{array}$ & $\begin{array}{l}\text { Opportunity } \\
\text { growth gap }\end{array}$ & $\begin{array}{c}\text { Income } \\
\text { growth gap }\end{array}$ & $\begin{array}{l}\text { Opportunity } \\
\text { growth gap }\end{array}$ & $\begin{array}{c}\text { Income } \\
\text { growth gap }\end{array}$ & $\begin{array}{l}\text { Opportunity } \\
\text { growth gap }\end{array}$ \\
\hline Severe action & $\begin{array}{c}-0.006 * * * \\
(-3.13)\end{array}$ & $\begin{array}{c}-0.005 * * * \\
(-3.33)\end{array}$ & & & $\begin{array}{c}-0.027 * * * \\
(-2.76)\end{array}$ & $\begin{array}{c}-0.032 * * * \\
(-4.47)\end{array}$ & & & $\begin{array}{c}-0.036^{* *} \\
(-2.50)\end{array}$ & $\begin{array}{c}-0.034 * * * \\
(-3.63)\end{array}$ & & \\
\hline Less severe action & $\begin{array}{l}-0.001 \\
(-0.23)\end{array}$ & $\begin{array}{l}-0.001 \\
(-0.77)\end{array}$ & $\begin{array}{l}-0.001 \\
(-0.25)\end{array}$ & $\begin{array}{l}-0.001 \\
(-0.79)\end{array}$ & $\begin{array}{l}0.001 \\
(0.06)\end{array}$ & $\begin{array}{l}-0.002 \\
(-0.22)\end{array}$ & $\begin{array}{l}0.001 \\
(0.02)\end{array}$ & $\begin{array}{l}-0.002 \\
(-0.27)\end{array}$ & $\begin{array}{l}-0.007 \\
(-0.47)\end{array}$ & $\begin{array}{l}-0.008 \\
(-0.79)\end{array}$ & $\begin{array}{l}-0.007 \\
(-0.47)\end{array}$ & $\begin{array}{l}-0.008 \\
(-0.80)\end{array}$ \\
\hline Formal agreement & & & $\begin{array}{c}-0.006 * * \\
(-2.49)\end{array}$ & $\begin{array}{c}-0.006 * * * \\
(-2.67)\end{array}$ & & & $\begin{array}{c}-0.022^{*} \\
(-1.76)\end{array}$ & $\begin{array}{c}-0.028 * * * \\
(-2.82)\end{array}$ & & & $\begin{array}{c}-0.036 * * \\
(-2.12)\end{array}$ & $\begin{array}{c}-0.033 * * \\
(-2.43)\end{array}$ \\
\hline Cease and desist order & & & $\begin{array}{c}-0.006^{* *} \\
(-2.16)\end{array}$ & $\begin{array}{c}-0.005^{* *} \\
(-2.41)\end{array}$ & & & $\begin{array}{c}-0.034 * * \\
(-2.58)\end{array}$ & $\begin{array}{c}-0.036 * * * \\
(-3.71)\end{array}$ & & & $\begin{array}{l}-0.024 \\
(-1.14)\end{array}$ & $\begin{array}{c}-0.028 * * \\
(-2.26)\end{array}$ \\
\hline Prompt corrective action & & & $\begin{array}{l}-0.013 \\
(-0.88)\end{array}$ & $\begin{array}{l}-0.004 \\
(-0.43)\end{array}$ & & & $\begin{array}{l}0.002 \\
(0.03)\end{array}$ & $\begin{array}{l}-0.031 \\
(-0.60)\end{array}$ & & & $\begin{array}{c}-0.192 * * \\
(-2.33)\end{array}$ & $\begin{array}{c}-0.120 * * \\
(-2.52)\end{array}$ \\
\hline Control variables & & & & & & & & & & & & \\
\hline Demand & $\begin{array}{c}0.001 * * * \\
(24.85)\end{array}$ & $\begin{array}{c}0.001 * * * \\
(29.01)\end{array}$ & $\begin{array}{c}0.001 * * * \\
(24.89)\end{array}$ & $\begin{array}{c}0.001 * * * \\
(28.91)\end{array}$ & $\begin{array}{c}0.002 * * * \\
(11.24)\end{array}$ & $\begin{array}{c}0.002 * * * \\
(13.47)\end{array}$ & $\begin{array}{c}0.002 * * * \\
(11.15)\end{array}$ & $\begin{array}{c}0.002 * * * \\
(13.36)\end{array}$ & $\begin{array}{c}0.001 * * * \\
(3.61)\end{array}$ & $\begin{array}{c}0.001 * * * \\
(5.14)\end{array}$ & $\begin{array}{c}0.001 * * * \\
(3.47)\end{array}$ & $\begin{array}{c}0.001 * * * \\
(5.03)\end{array}$ \\
\hline HHI (ln) & $\begin{array}{l}0.002 \\
(1.17)\end{array}$ & $\begin{array}{l}0.000 \\
(0.08)\end{array}$ & $\begin{array}{l}0.002 \\
(1.13)\end{array}$ & $\begin{array}{l}0.000 \\
(0.04)\end{array}$ & $\begin{array}{c}-0.048 * * * \\
(-3.26)\end{array}$ & $\begin{array}{c}-0.141 * * * \\
(-7.48)\end{array}$ & $\begin{array}{c}-0.049 * * * \\
(-3.30)\end{array}$ & $\begin{array}{c}-0.142 * * * \\
(-7.53)\end{array}$ & $\begin{array}{l}-0.033 \\
(-1.44)\end{array}$ & $\begin{array}{c}-0.146 * * * \\
(-6.16)\end{array}$ & $\begin{array}{l}-0.033 \\
(-1.45)\end{array}$ & $\begin{array}{c}-0.146^{* * *} \\
(-6.20)\end{array}$ \\
\hline Firm size (ln) & $\begin{array}{l}0.002 \\
(1.16)\end{array}$ & $\begin{array}{l}0.002 \\
(0.96)\end{array}$ & $\begin{array}{l}0.002 \\
(1.15)\end{array}$ & $\begin{array}{l}0.002 \\
(0.96)\end{array}$ & $\begin{array}{c}0.014 * * \\
(2.00)\end{array}$ & $\begin{array}{l}0.009 \\
(1.30)\end{array}$ & $\begin{array}{c}0.014 * * \\
(1.99)\end{array}$ & $\begin{array}{l}0.009 \\
(1.31)\end{array}$ & $\begin{array}{l}0.023^{*} \\
(1.68)\end{array}$ & $\begin{array}{l}0.005 \\
(0.47)\end{array}$ & $\begin{array}{l}0.023^{*} \\
(1.69)\end{array}$ & $\begin{array}{l}0.005 \\
(0.48)\end{array}$ \\
\hline Population & $\begin{array}{c}-0.486 * * * \\
(-7.41)\end{array}$ & $\begin{array}{c}-0.298 * * * \\
(-4.82)\end{array}$ & $\begin{array}{c}-0.485 * * * \\
(-7.41)\end{array}$ & $\begin{array}{c}-0.298 * * * \\
(-4.83)\end{array}$ & $\begin{array}{c}0.514 * * \\
(2.34)\end{array}$ & $\begin{array}{l}0.379 \\
(1.47)\end{array}$ & $\begin{array}{c}0.513^{* *} \\
(2.34)\end{array}$ & $\begin{array}{l}0.381 \\
(1.47)\end{array}$ & $\begin{array}{c}0.605^{*} \\
(1.81)\end{array}$ & $\begin{array}{c}0.476^{*} \\
(1.70)\end{array}$ & $\begin{array}{c}0.616^{*} \\
(1.82)\end{array}$ & $\begin{array}{c}0.485^{*} \\
(1.71)\end{array}$ \\
\hline Crisis & $\begin{array}{c}-0.049 * * * \\
(-25.00)\end{array}$ & $\begin{array}{c}-0.040 * * * \\
(-27.36)\end{array}$ & $\begin{array}{c}-0.049 * * * \\
(-24.89)\end{array}$ & $\begin{array}{c}-0.040 * * * \\
(-27.23)\end{array}$ & $\begin{array}{c}-0.110 * * * \\
(-11.64)\end{array}$ & $\begin{array}{c}-0.096 * * * \\
(-12.92)\end{array}$ & $\begin{array}{c}-0.110 * * * \\
(-11.54)\end{array}$ & $\begin{array}{c}-0.095 * * * \\
(-12.82)\end{array}$ & $\begin{array}{c}-0.231 * * * \\
(-14.15)\end{array}$ & $\begin{array}{c}-0.183 * * * \\
(-17.94)\end{array}$ & $\begin{array}{c}-0.230 * * * \\
(-14.02)\end{array}$ & $\begin{array}{c}-0.182 * * * \\
(-17.84)\end{array}$ \\
\hline County fixed effects & Yes & Yes & Yes & Yes & Yes & Yes & Yes & Yes & Yes & Yes & Yes & Yes \\
\hline Year fixed effects & Yes & Yes & Yes & Yes & Yes & Yes & Yes & Yes & Yes & Yes & Yes & Yes \\
\hline Observations & 9,277 & 9,242 & 9,277 & 9,242 & 9,277 & 9,242 & 9,277 & 9,242 & 9,277 & 9,242 & 9,277 & 9,242 \\
\hline R-squared & 0.310 & 0.342 & 0.310 & 0.342 & 0.126 & 0.163 & 0.126 & 0.164 & 0.129 & 0.157 & 0.129 & 0.157 \\
\hline Interventions & 782 & 787 & 782 & 787 & 782 & 787 & 782 & 787 & 782 & 787 & 782 & 787 \\
\hline
\end{tabular}

Notes. This table presents results of difference-in-difference regressions of enforcement actions in single-market banks on per capita personal income growth on the county level, and we also explore two possible mechanisms, total loan growth, and liquidity creation growth for the effect of enforcement actions on per capita personal income growth. We present regressions with two alternative control groups. The first control group, used in the regressions denoted with an a), consist of counties adjacent to counties in the treatment group, matched on the pretreatment per capita personal income growth to account for convergence effects and spillover effects of counties that are located in close proximity. The second set of regressions accounts for the growth opportunity gap between treatment and control group counties. The growth opportunity gap is determined by industry specific factors at the county level, e.g., composition of the local industrial structure which determines growth rates differentially. Coding of enforcement actions follows the exposition reported above in the notes to Table 3 . All control variables reported in Table 3 are also included. Delaware and South Dakota counties excluded. We report robust $\mathrm{t}$-statistics in parentheses, and errors are clustered on the county level. $* * * \mathrm{p}<0.01, * * \mathrm{p}<0.05$, * $\mathrm{p}<0.1$. 
Table 6

Propensity score matching: Effect of enforcement actions

Panel A: Per capita personal income growth

Severe action

Less severe action

\begin{tabular}{|c|c|c|c|c|c|}
\hline & Severe action & Less severe action & Formal agreement & Cease and desist order & Prompt corrective action \\
\hline Matches $(n=2)$ & $-0.011^{* * *}$ & -0.001 & $-0.010^{* *}$ & $-0.010^{* * *}$ & $-0.058^{* *}$ \\
\hline z-statistic & $(-3.87)$ & $(-0.07)$ & $(-2.11)$ & $(-2.82)$ & $(-2.13)$ \\
\hline Observations & 15,329 & 15,329 & 15,329 & 15,329 & 15,329 \\
\hline Matches $(n=4)$ & $-0.012 * * *$ & 0.001 & $-0.011 * * *$ & $-0.011 * * *$ & $-0.057 * * *$ \\
\hline z-statistic & $(-4.20)$ & $(0.06)$ & $(-2.63)$ & $(-2.95)$ & $(-2.89)$ \\
\hline Observations & 15,329 & 15,329 & 15,329 & 15,329 & 15,329 \\
\hline
\end{tabular}

Panel B: Total loan growth

\begin{tabular}{|c|c|c|c|c|c|}
\hline & Severe action & Less severe action & Formal agreement & Cease and desist order & Prompt corrective action \\
\hline Matches $(n=2)$ & $-0.028 * *$ & -0.006 & $-0.029 * *$ & $-0.034 * *$ & 0.038 \\
\hline z-statistic & $(-2.49)$ & $(-0.50)$ & $(-2.26)$ & $(-2.09)$ & $(0.28)$ \\
\hline Observations & 15,329 & 15,329 & 15,329 & 15,329 & 15,329 \\
\hline Matches $(n=4)$ & $-0.030^{* * *}$ & -0.004 & $-0.030 * * *$ & $-0.039 * * *$ & 0.050 \\
\hline z-statistic & $(-2.89)$ & $(-0.35)$ & $(-2.60)$ & $(-2.77)$ & $(0.38)$ \\
\hline Observations & 15,329 & 15,329 & 15,329 & 15,329 & 15,329 \\
\hline
\end{tabular}

\section{Panel C: Liquidity creation growth}

\begin{tabular}{|c|c|c|c|c|c|}
\hline & Severe action & Less severe action & Formal agreement & Cease and desist order & Prompt corrective action \\
\hline Matches $(n=2)$ & $-0.062 * * *$ & $-0.037 * *$ & $-0.053^{* *}$ & $-0.049^{*}$ & $-0.349 * * *$ \\
\hline z-statistic & $(-3.50)$ & $(-2.11)$ & $(-2.50)$ & $(-1.73)$ & $(-3.92)$ \\
\hline Observations & 15,329 & 15,329 & 15,329 & 15,329 & 15,329 \\
\hline Matches $(n=4)$ & $-0.060 * * *$ & $-0.036^{* *}$ & $-0.054 * * *$ & $-0.056^{* *}$ & $-0.339 * * *$ \\
\hline z-statistic & $(-3.47)$ & $(-2.14)$ & $(-2.79)$ & $(-2.35)$ & $(-4.27)$ \\
\hline Observations & 15,329 & 15,329 & 15,329 & 15,329 & 15,329 \\
\hline
\end{tabular}

Notes. The table presents results for the effect of enforcement actions on real per capita personal income growth in Panel A, total loan growth in Panel B, and liquidity creation in

Panel C using propensity score methods based on nearest neighbour matches. This technique uses probit models to estimate the probability of Severe and Less severe actions (including Formal agreements, Cease and desist orders, and Prompt corrective actions) for the propensity scores. Matching variables include deposit-based Herfindahl-Hirschman Index, population growth, and average firms size in the county. We present results for models using 2 and 4 matching countries in the control group. Delaware and South Dakota counties excluded.Robust $\mathrm{z}$-statistics in brackets. *** $\mathrm{p}<0.01 ; * * \mathrm{p}<0.05, * \mathrm{p}<0.1$ 
Table 7

Instrumental variables regressions: The effect of enforcement actions

\begin{tabular}{|c|c|c|c|c|c|c|c|c|c|c|c|c|c|c|c|}
\hline & & & & & & \multicolumn{10}{|c|}{ Mechanism } \\
\hline & \multicolumn{5}{|c|}{ Personal income growth } & \multicolumn{5}{|c|}{ Total loan growth } & \multicolumn{5}{|c|}{ Liquidity creation growth } \\
\hline & (1) & (2) & (3) & (4) & (5) & (6) & (7) & (8) & $(9)$ & (10) & (11) & (12) & (13) & (14) & (15) \\
\hline \multicolumn{16}{|l|}{ Second stage results } \\
\hline Severe action & $\begin{array}{c}-0.163 * * * * \\
(-3.76)\end{array}$ & & & & & $\begin{array}{c}-0.574 * * * * \\
(-3.65)\end{array}$ & & & & & $\begin{array}{c}-0.372 * * * \\
(-2.58)\end{array}$ & & & & \\
\hline Less severe action & & $\begin{array}{l}1.308 \\
(1.12)\end{array}$ & & & & & $\begin{array}{l}4.610 \\
(1.10)\end{array}$ & & & & & $\begin{array}{l}2.965 \\
(1.05)\end{array}$ & & & \\
\hline Formal agreements & & & $\begin{array}{c}-0.338^{* * *} \\
(-2.33)\end{array}$ & & & & & $\begin{array}{c}-1.187 * * \\
(-2.40)\end{array}$ & & & & & $\begin{array}{c}-0.768 * * \\
(-1.98)\end{array}$ & & \\
\hline Cease and desist order & & & & $\begin{array}{c}-0.174 * * * \\
(-3.90)\end{array}$ & & & & & $\begin{array}{c}-0.612^{* * * *} \\
(-3.60)\end{array}$ & & & & & $\begin{array}{c}-0.396 * * * * \\
(-2.58)\end{array}$ & \\
\hline Prompt corrective action & & & & & $\begin{array}{l}-2.449 \\
(-0.77)\end{array}$ & & & & & $\begin{array}{l}-8.626 \\
(-0.78)\end{array}$ & & & & & $\begin{array}{l}-5.568 \\
(-0.76)\end{array}$ \\
\hline Controls & Yes & Yes & Yes & Yes & Yes & Yes & Yes & Yes & Yes & Yes & Yes & Yes & Yes & Yes & Yes \\
\hline County fixed effects & Yes & Yes & Yes & Yes & Yes & Yes & Yes & Yes & Yes & Yes & Yes & Yes & Yes & Yes & Yes \\
\hline \multirow{2}{*}{\multicolumn{16}{|c|}{ First stage results }} \\
\hline & & & & & & & & & & & & & & & \\
\hline Assessment fees* Distance to FDIC & $\begin{array}{c}0.000 * * * \\
(4.44)\end{array}$ & $\begin{array}{l}-0.000 \\
(-1.12)\end{array}$ & $\begin{array}{c}0.000^{* * *} \\
(2.53)\end{array}$ & $\begin{array}{c}0.000^{* * * *} \\
(4.50)\end{array}$ & $\begin{array}{l}0.000 \\
(0.77)\end{array}$ & $\begin{array}{c}0.000^{* * * *} \\
(4.44)\end{array}$ & $\begin{array}{l}-0.000 \\
(-1.12)\end{array}$ & $\begin{array}{c}0.000 * * \\
(2.53)\end{array}$ & $\begin{array}{c}0.000^{* * * *} \\
(4.50)\end{array}$ & $\begin{array}{l}0.000 \\
(0.77)\end{array}$ & $\begin{array}{c}0.000 * * * \\
(4.44)\end{array}$ & $\begin{array}{l}-0.000 \\
(-1.12)\end{array}$ & $\begin{array}{c}0.000^{* *} \\
(2.53)\end{array}$ & $\begin{array}{c}0.000^{* * * *} \\
(4.50)\end{array}$ & $\begin{array}{l}0.000 \\
(0.77)\end{array}$ \\
\hline Distance to FDIC & $\begin{array}{l}-0.000 \\
(-1.62)\end{array}$ & $\begin{array}{l}0.000 \\
(0.26)\end{array}$ & $\begin{array}{c}-0.000 * * \\
(-2.07)\end{array}$ & $\begin{array}{c}-0.000 * * \\
(-2.35)\end{array}$ & $\begin{array}{l}-0.000 \\
(-0.20)\end{array}$ & $\begin{array}{l}-0.000 \\
(-1.62)\end{array}$ & $\begin{array}{l}0.000 \\
(0.26)\end{array}$ & $\begin{array}{c}-0.000^{* *} \\
(-2.07)\end{array}$ & $\begin{array}{c}-0.000^{* *} \\
(-2.35)\end{array}$ & $\begin{array}{l}-0.000 \\
(-0.20)\end{array}$ & $\begin{array}{l}-0.000 \\
(-1.62)\end{array}$ & $\begin{array}{l}0.000 \\
(0.26)\end{array}$ & $\begin{array}{c}-0.000 * * \\
(-2.07)\end{array}$ & $\begin{array}{c}-0.000 * * \\
(-2.35)\end{array}$ & $\begin{array}{l}-0.000 \\
(-0.20)\end{array}$ \\
\hline Monitoring index & $\begin{array}{c}0.003^{* * * *} \\
(3.04) \\
\end{array}$ & $\begin{array}{l}-0.001 \\
(-1.30) \\
\end{array}$ & $\begin{array}{c}0.002 * * \\
(2.00) \\
\end{array}$ & $\begin{array}{c}0.004 * * * * \\
(3.66) \\
\end{array}$ & $\begin{array}{l}0.000 \\
(0.84) \\
\end{array}$ & $\begin{array}{c}0.003^{* * * *} \\
(3.04) \\
\end{array}$ & $\begin{array}{l}-0.001 \\
(-1.30) \\
\end{array}$ & $\begin{array}{c}0.002 * * \\
(2.00) \\
\end{array}$ & $\begin{array}{c}0.004 * * * \\
(3.66) \\
\end{array}$ & $\begin{array}{l}0.000 \\
(0.84) \\
\end{array}$ & $\begin{array}{c}0.003^{* * * *} \\
(3.04) \\
\end{array}$ & $\begin{array}{l}-0.001 \\
(-1.30) \\
\end{array}$ & $\begin{array}{c}0.002^{* * *} \\
(2.00) \\
\end{array}$ & $\begin{array}{c}0.004 * * * * \\
(3.66) \\
\end{array}$ & $\begin{array}{l}0.000 \\
(0.84) \\
\end{array}$ \\
\hline Observations & 14,531 & 14,531 & 14,531 & 14,531 & 14,531 & 14,531 & 14,531 & 14,531 & 14,531 & 14,531 & 14,531 & 14,531 & 14,531 & 14,531 & 14,531 \\
\hline R-squared & -0.145 & -20.134 & -0.543 & -0.041 & -2.385 & -0.167 & -13.787 & -0.441 & -0.094 & -1.727 & 0.038 & -1.847 & 0.000 & 0.046 & -0.163 \\
\hline Kleibergen-Paap rk LM statistic & 104.1 & 9.529 & 122.6 & 197.0 & 43.51 & 104.1 & 9.529 & 122.6 & 197.0 & 43.51 & 104.1 & 9.529 & 122.6 & 197.0 & 43.51 \\
\hline Kleibergen-Paap F-statistic & 30.00 & 3.065 & 25.10 & 46.91 & 11.69 & 30.00 & 3.065 & 25.10 & 46.91 & 11.69 & 30.00 & 3.065 & 25.10 & 46.91 & 11.69 \\
\hline Hansen J statistic p-value & 0.118 & 0.415 & 0.221 & 0.177 & 0.474 & 0.314 & 0.541 & 0.511 & 0.475 & 0.649 & 0.890 & 0.673 & 0.959 & 0.888 & 0.752 \\
\hline
\end{tabular}


Table 8

Difference-in-difference regressions: The effect of enforcement actions on growth of different types of loans

\begin{tabular}{|c|c|c|c|c|c|c|c|c|c|c|}
\hline \multicolumn{3}{|c|}{ Panel A: Agricultural production loans } & \multirow{2}{*}{\multicolumn{2}{|c|}{$\begin{array}{l}\text { Panel B: Commercial and industrial loans } \\
-0.43^{* * * *}\end{array}$}} & \multirow{2}{*}{\multicolumn{2}{|c|}{\begin{tabular}{|c|} 
Panel C: Consumer loans \\
$-0.025^{* * *}$
\end{tabular}}} & \multirow{2}{*}{\multicolumn{2}{|c|}{$\begin{array}{l}\text { Panel D: Real estate loans } \\
-0.020^{* * *}\end{array}$}} & \multirow{2}{*}{\multicolumn{2}{|c|}{ Panel E: Loans to other depository institutions }} \\
\hline Severe action & $-0.032^{* * * 2}$ & & & & & & & & & \\
\hline & $(-2.69)$ & & $(-4.55)$ & & $(-2.68)$ & & $(-2.14)$ & & $(-2.70)$ & \\
\hline Less severe action & 0.007 & 0.006 & -0.010 & -0.011 & -0.009 & -0.009 & -0.001 & -0.002 & $\begin{array}{r}-0.125 \\
-118\end{array}$ & -0.123 \\
\hline & $(0.54)$ & $(0.49)$ & $(-0.99)$ & $(-1.07)$ & $(-0.86)$ & $(-0.89)$ & $(-0.17)$ & $(-0.23)$ & $(-1.18)$ & $(-1.15)$ \\
\hline Cease and desist order & & $-0.042^{* * * *}$ & & $-0.057 * * * *$ & & $-0.027 * * *$ & & $-0.024 *$ & & -0.110 \\
\hline Formal agreement & & $\begin{array}{l}(-2.78) \\
-0.025\end{array}$ & & $\begin{array}{l}(-4 . / 2) \\
-0.031 * *\end{array}$ & & ${ }_{-0.022}^{(-2.34)}$ & & $\begin{array}{c}(-1.91) \\
-0.021 *\end{array}$ & & $\begin{array}{c}(-1.21) \\
-0.190 * *\end{array}$ \\
\hline & & $(-1.37)$ & & $(-2.33)$ & & $\begin{array}{l}-0.022 \\
(-1.60)\end{array}$ & & $(-1.70)$ & & $(-2.00)$ \\
\hline Prompt corrective action & & -0.019 & & -0.012 & & 0.001 & & -0.043 & & -0.248 \\
\hline & & $(-0.23)$ & & $(-0.14)$ & & $(0.02)$ & & $(-0.61)$ & & $(-1.10)$ \\
\hline Control variables & Yes & Yes & Yes & Yes & Yes & Yes & Yes & Yes & Yes & Yes \\
\hline Observations & 15,267 & 15,267 & 15,329 & 15,329 & 15,329 & 15,329 & 15,329 & 15,329 & 10,738 & 10,738 \\
\hline R-squared & 0.135 & 0.135 & 0.209 & 0.209 & 0.170 & 0.170 & 0.145 & 0.145 & 0.182 & 0.182 \\
\hline Number of interventions & 828 & 828 & 828 & 828 & 828 & 828 & 828 & 828 & 676 & 676 \\
\hline
\end{tabular}

Notes. The table presents results of difference-in-difference regressions of Severe and Less severe enforcement actions in single market banks on growth of loans on the county level for different types of lending activities. All variables are defined in the notes to Table 3. Delaware and South Dakota counties excluded.Robust t-statistics in parentheses. Standard errors are clustered on the county level.. *** $\mathrm{p}<0.01, * * \mathrm{p}<0.05,{ }^{*} \mathrm{p}<0.1$. 
Figure 1

Local banking markets in the U.S. (Development over time)

Figure 1 presents the location and number of counties in which single-market banks operate, at the beginning and the end of the sample period (2001 and 2009). Counties shaded in red represent counties in which all operating banks are single market banks. Counties shaded in green color are counties where at least one single market is located. All other counties are shaded in blue color.

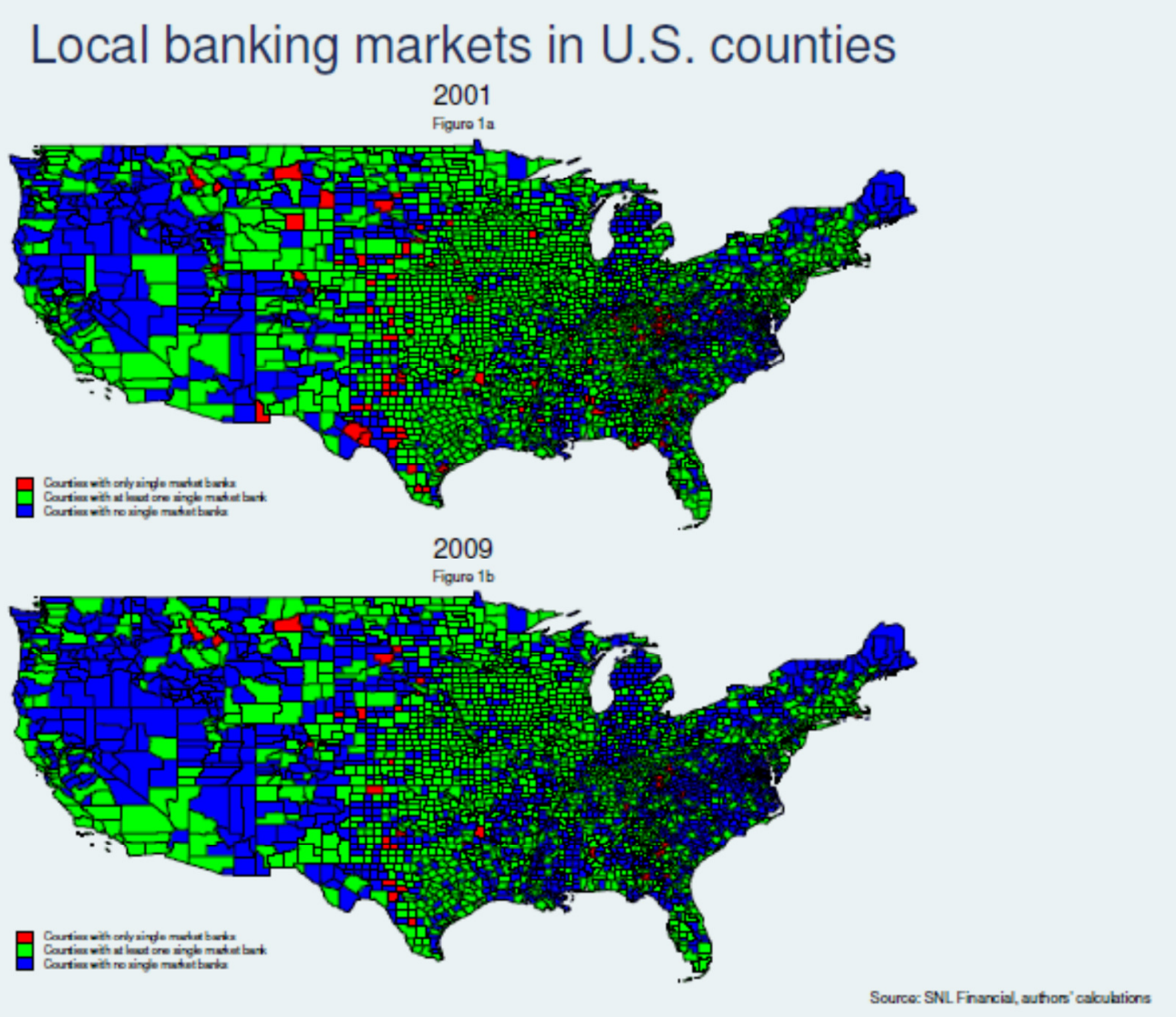


Figure 2

Enforcement actions in U.S. counties (Development over time)

Figure 2 presents the location and number of counties in which single market banks were subject to regulatory enforcement actions. We present their location and number at the beginning and the end of the sample period (year 2001 and 2009). Counties shaded in red represent intervention counties. All other counties are shaded in blue color.

\section{Enforcement actions in U.S. counties}

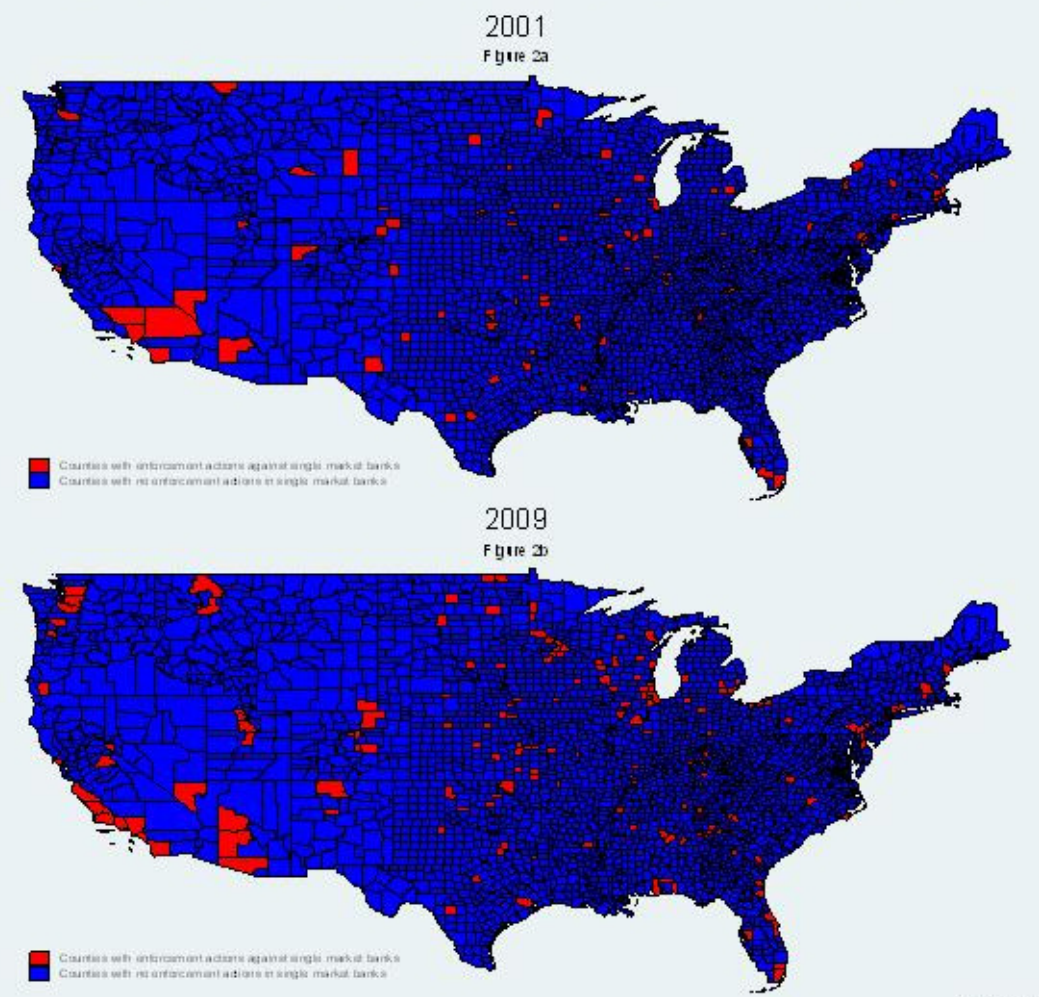

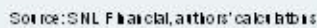


Figure 3

Timing of enforcement actions

Figure 3 shows the year of severe and less severe enforcement actions and the average level of dependent variables (real per capita income growth, lending growth and liquidity creation growth) prior to the intervention.
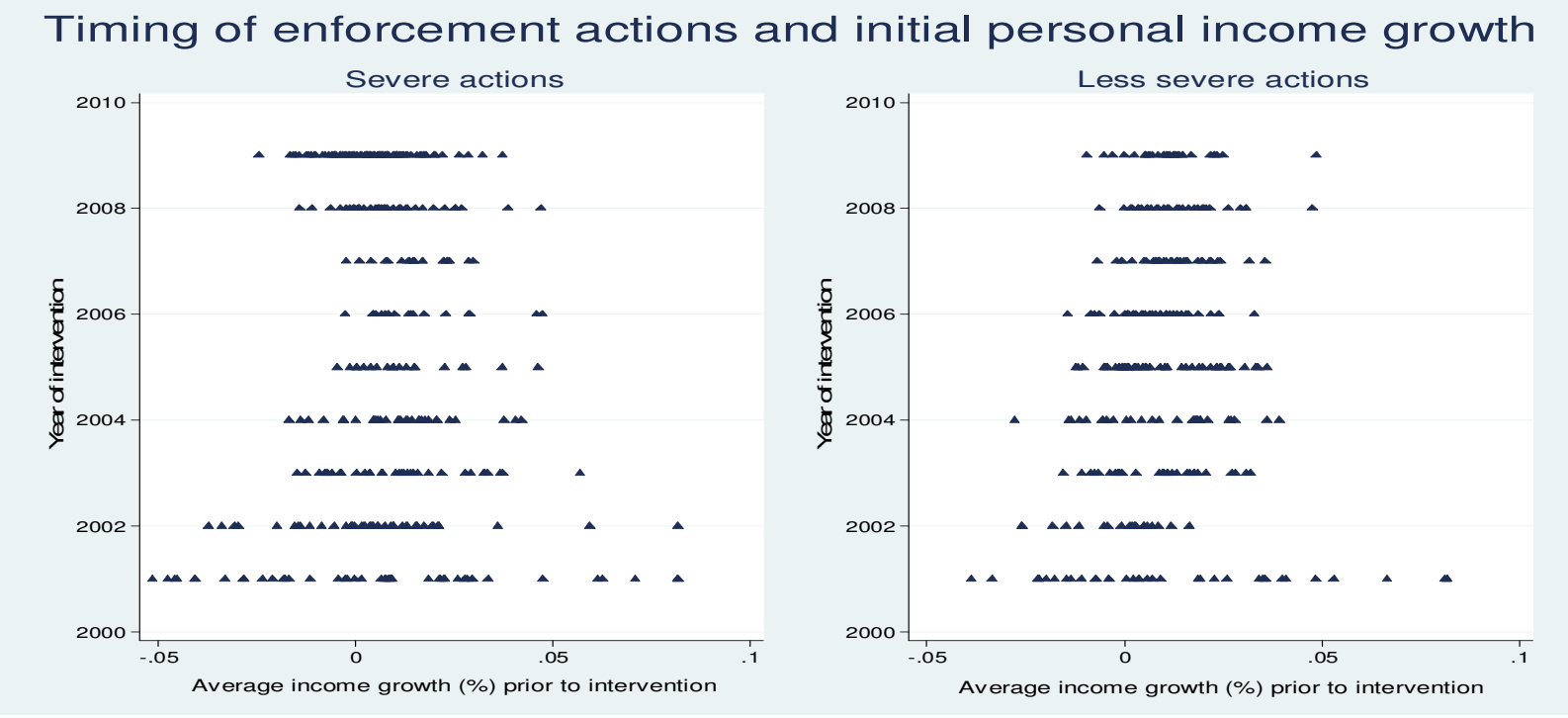
Figure 4

Parallel trends between treatment and control group

Figure 4 compares development of dependent variables (personal income, total lending and liquidity creation) three years prior to the enforcement of severe and less severe actions for treatment (triangles) and control (squares) group counties.

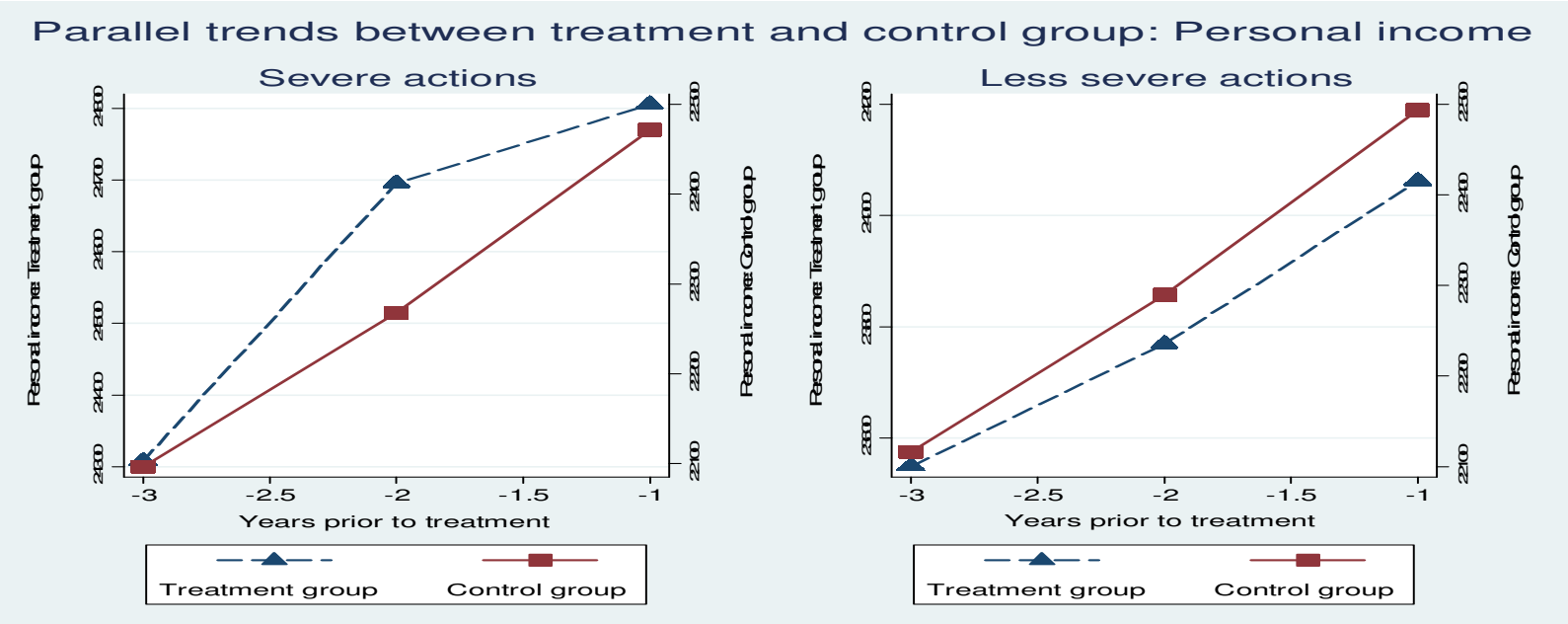

